\title{
Tectonic Inversion and Geomorphic Evolution of the Algerian Margin Since Messinian Times: Insights From New Onshore/Offshore Analog Modeling Experiments
}

\author{
Pierre Strzerzynski ${ }^{1}$ (D), Stéphane Dominguez ${ }^{2}$ (D), Azzedine Boudiaf ${ }^{2}$, and Jacques Déverchère ${ }^{3}$ (i) \\ ${ }^{1}$ Laboratoire de Planétologie et de Géodynamique, CNRS, Le Mans Université, Le Mans, France, ${ }^{2}$ Géosciences \\ Montpellier, CNRS, Université de Montpellier, Montpellier, France, ${ }^{3}$ Géosciences Océan, Université de Brest, CNRS, \\ Plouzané, France
}

\begin{abstract}
Tectonic inversion of passive margins is a common but poorly documented process preceding subduction inception. We perform here a comprehensive land-sea experimental modeling of this key process by reproducing the morphotectonic and sedimentary evolution of the central Algerian margin over the last $6 \mathrm{Myr}$. Our approach is based on scaled analog models integrating interactions between crustal shortening and surface processes, including erosion, water transport, sedimentation, gravitational instabilities, and base-level changes. A challenge was to simulate the effects of the Messinian Salinity Crisis (MSC) through a major sea-level oscillation and halite deposition. By using realistic boundary conditions, adapted analog material, and robust, first-order parameters for physiography setups, we successfully reproduce the morphotectonic domains and the time-dependent geometrical relationships between fluvio-deltaic sedimentary systems, erosional surfaces, and thrust faults as observed since Messinian times. Our results highlight (1) the key role played by the MSC sea-level oscillation on an ultra-fast building, destruction and re-sedimentation of fans and deltas from the upper slope to the abyssal plain; (2) the development of a large popup structure subparallel to the coastline, with progressive strain migration from the backthrust on land toward a frontal thrust of opposite vergence at mid-slope and the margin toe; and (3) the importance of lateral changes in initial wedge shape and strain distribution for determining the non-cylindrical geometry of the margin and progradation of piggy-back basins during tectonic inversion. Our results support that the central Algerian margin is witnessing the early building of an accretionary wedge combining thin-skinned and thick-skinned tectonic styles.
\end{abstract}

\section{Introduction}

Tectonic inversion refers to geological processes involving the reactivation of extensional basin structures in response to crustal shortening or the reactivation of reverse faults during crustal extension (e.g., M. P. Coward, 1996; M. P. Coward et al., 1991; Dewey, 1989; Turner \& Williams, 2004; Williams et al., 1989; Ziegler et al., 1995). This comprehensive definition includes studies focused on the inversion at different scales, ranging from a single fault system up to basins and margins. Studied examples of passive margin inversion are numerous. Most of the time, these objects are represented by advanced stages of inversion nowadays incorporated in the heart of mountain ranges (e.g., Beltrando et al., 2014; Carmignani et al., 2004; Shail \& Leveridge, 2009; Vanbrabant et al., 2002). If several field examples are documenting early stages of fossil margin inversion, the ongoing inversion of passive margins witnessing a process of subduction initiation is seldom found because it represents a short, transient phase before the onset of stable subduction (Kim et al., 2018; Stern \& Gerya, 2018). The central Algerian margin (Western Mediterranean Sea, Figure 1) represents, then, one of the rare and best examples of present-day inversion of a passive margin in the early stages.

The Algerian margin is made of basement blocks (mainly, the greater and lesser Kabylies) that migrated from the European margin and docked against the African plate in the Early Miocene, in response to the southward rollback of the Maghrebian Tethyan slab (van Hinsbergen et al., 2014; R. Leprêtre et al., 2018, and references therein). The area has received special attention over the last 20 years, especially after the occurrence of the Boumerdès earthquake $\left(M_{w}=6.9,2003\right.$; Ayadi et al., 2003). Geophysical studies since then have evidenced that the Algerian margin is experiencing crustal shortening and a generalized tectonic inversion possibly leading to subduction inception (Hamai et al., 2015, 2018; Strzerzynski et al., 2010; Yelles 


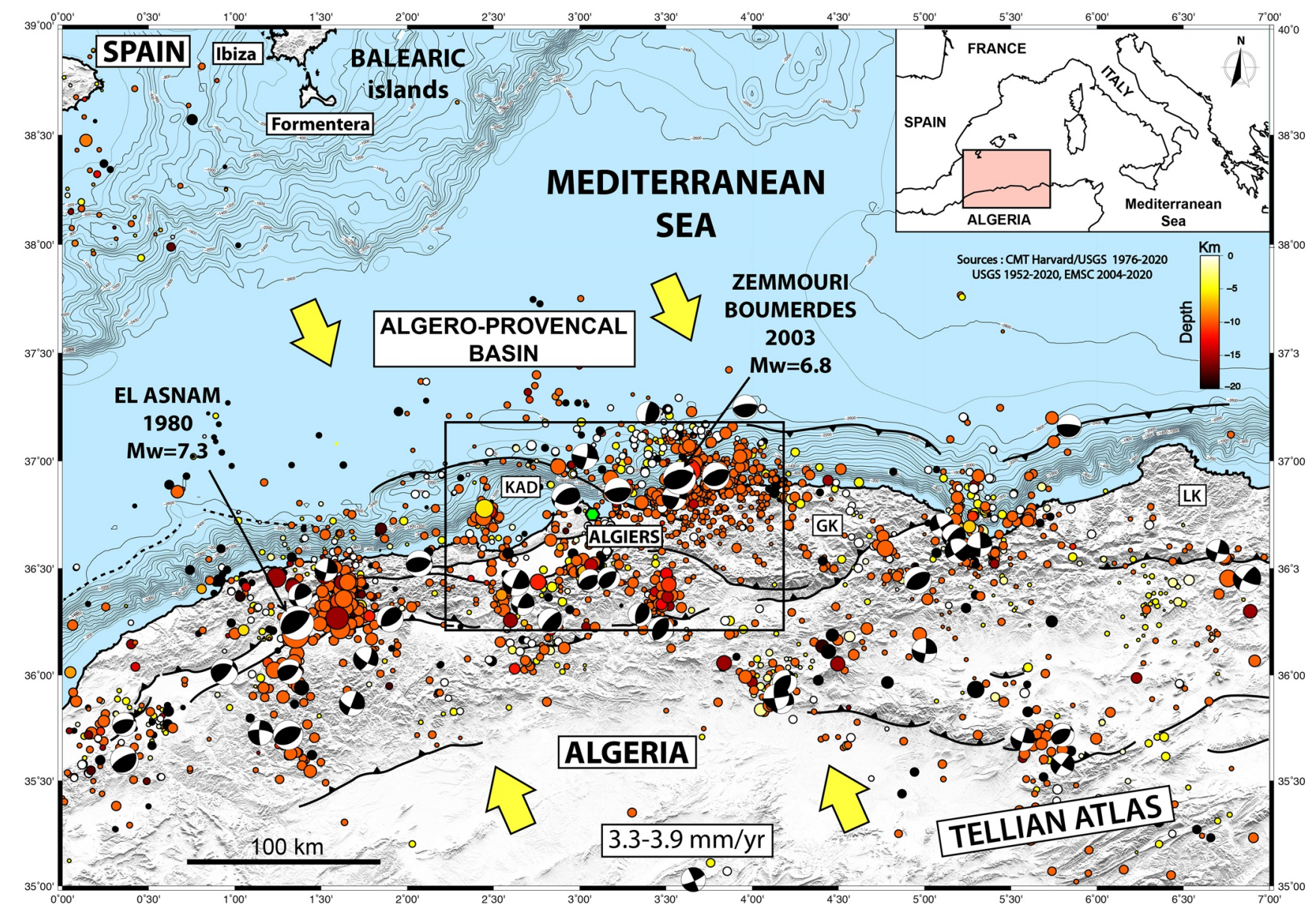

Figure 1. Simplified tectonic map of North Algeria and the Algerian margin showing instrumental seismicity from CMT USGS-Harvard and EMSC earthquake catalogs. Digital earth model after SRTM Nasa topographic mission, bathymetric data after GEBCO Bathymetric compilation project, mean Africa-Eurasia relative motion from GPS data (Bougrine et al., 2019), major faults after Yelles et al. (2006) and Rabaute and Chamot-Rooke (2014). Inset locates the area shown in Figure 2.

et al., 2009). In Lesser Kabylia, a first cooling episode between 17 and 15 Ma was followed by a kilometer-scale exhumation between 9 and $7 \mathrm{Ma}$, interpreted as a consequence of slab breakoff and the formation of imbricated thrust sheets in the upper margin, respectively (Recanati et al., 2019). Recent geodetic results in Algeria demonstrate that the offshore fault system, running along the toe of the central Algerian margin, possibly accommodates $1.5 \mathrm{~mm}$ /year of shortening, in contrast with the coastal domain of the Tell and Kabylies where strain rates are very low (Bougrine et al., 2019). Thermo-dynamical modeling suggests that the relatively high geothermal gradient and the deep inherited structures of the stretched continental margin contribute to weaken the margin and to focus compressional deformation at the margin toe (Hamai et al., 2018).

However, the way the tectonic deformation developed and migrated through times across the whole passive margin is not fully understood, and the role played by structures inherited from the Tethyan slab rollback since the collision of the Kabylian blocks remains unclear. Furthermore, the Algerian margin, like all margins of the Mediterranean Sea, has recorded the strong imprint of the Messinian Salinity Crisis (MSC), giving birth to specific seismic markers, sedimentary units and structures related to a giant sea-level oscillation and the occurrence of post-MSC deep salt tectonics (Lofi, Déverchère, et al., 2011; Lofi, Sage, et al., 2011; Dal Cin et al., 2016, and references therein). An impact of the MSC event on the vertical evolution of the margin due to isostasy effects has been also evoked in several studies (e.g., Govers et al., 2009; Norman and Chase, 1986; Rabineau et al., 2014). This brief and dramatic event thus offers the opportunity to highlight the relationships between tectonic reactivation and sea-level related sedimentary dynamics at a passive margin toe. 
In this paper, three main questions are addressed: (1) What is the tectonic, sedimentary, and morphologic evolution of the Algerian margin since Late Tortonian times, which is assumed to date the onset of the margin inversion on land (Recanati et al., 2019)? (2) How is the geometry and style of the thrust system evolving through time and how much does it look like an accretionary wedge? And (3) can we quantify the role played by the MSC, and more specifically by the large sea-level drop assumed to have occurred at ca. 5.6 Ma?

To address these points, we complement the geological and geophysical observations by using a novel experimental approach, integrating jointly onshore and offshore tectonic and surface processes simulation.

Objectives of the present study are: (1) to briefly review available geological and geophysical data constraining the geodynamical and morphostructural evolution of the Algerian margin and introduce the hypothesis and models that have been proposed. Then, after selecting the most probable scenario and associated boundary conditions, (2) These constraint the initial conditions and the scenario of the analog model; (2) to investigate experimentally the morpho-tectonic evolution of the Algerian margin since the Messinian $(<-6 \mathrm{Myr})$ in order to highlight the processes controlling the timing and spatial distribution of the most recent tectonic phases of deformation (margin inversion), and finally (3) to better constrain the overall style of the tectonic inversion of a passive margin.

\section{Cenozoic Geodynamic Evolution of Northern Algeria}

The geology of northern Algeria is marked by a succession of geodynamic events occurring within the framework of the Africa-Eurasia plate convergence, that is, slab subduction and rollback, collision, and finally slab tearing. At Late Oligocene time, the decrease of the northward absolute motion of Africa is assumed to have triggered the rollback of the African (Tethyan) lithosphere, resulting in the southward migration of the internal ("ALKAPECA") zones and the opening of a back-arc extensional domain (Dewey et al., 1989; Gueguen et al., 1998; Jolivet \& Faccenna, 2000; Roca et al., 2004; Rosenbaum et al., 2004; Schettino \& Turco, 2006). Slab breakoff of the Tethyan oceanic lithosphere occurred at ca. 17 Ma, shortly after the end of the Algerian back-arc basin spreading and the continental collision of the Kabylian blocks with Africa. It induces initial isostatic uplift, the exhumation of high-pressure metamorphic rocks, and thermal erosion of the continental mantle during Burdigalian times and is followed by lateral slab tearing during Langhian-Serravalian times (Abbassene et al., 2016; Caby et al., 2001; Carminati et al., 1998; Chazot et al., 2017; Maury et al., 2000; van Hinsbergen et al., 2020). Further south, in the external zones, the Africa-Eurasia convergence has caused the inversion and orogenesis of the Atlas System during Eocene-Oligocene and Late Miocene-Pliocene, and the Tell shortening in the intervening period (Bouillin, 1986; Bracène \& Frizon de Lamotte, 2002; Frizon de Lamotte et al., 2000, 2009; Roure et al., 2012). To summarize, we may consider that the main mechanisms driving tectonic activity along the North Algerian margin since $30 \mathrm{Ma}$ are (1) the pull linked to the Maghrebian slab retreat until the collision of ALKAPECA with Africa, (2) the delamination of the African subcontinental mantle in response to slab breakoff and tearing since then, and (3) the tectonic inversion resulting in a Tortonian exhumation of the upper margin (Recanati et al., 2019) and a widespread post-Messinian emersion of the Algerian Tell (R. Leprêtre et al., 2018; Roure et al., 2012).

The end of the Miocene period is characterized by a giant Mediterranean sea-level drop (generally assumed to reach $-1,500 \mathrm{~m}$ ), called the MSC. This tectono-climatic event is responsible for the emersion and the deep erosion of the continental slopes surrounding the Mediterranean basins and the deposition of complex detritic bodies at the outlet of valleys. In the deep basin, the MSC is recorded by the deposition of a giant salt unit (Hsü et al., 1977; CIESM, 2008; Clauzon et al., 1996; Lofi, Déverchère, et al., 2011; Lofi, Sage, et al., 2011; Ryan \& Cita, 1978). The opening of the Strait of Gibraltar led to the flooding of the Mediterranean Sea that marked the end of the MSC (CIESM, 2008; Garcia-Castellanos et al., 2009). In upper margins, the post-Messinian sedimentary sequence corresponds to high-stand stacked prograding systems tracts emplaced after reflooding and resting upon a major erosional surface (MES for Margin Erosional Surface). They display an architecture similar to that of Gilbert-type deltas resulting either from fluvial or from wave-action dynamics (Clauzon et al., 1996; Duvail et al., 2005; Rubino et al., 2005). Although a final stratigraphic scenario is still not fully established and important controversial points remain, a chrono-stratigraphic model with three main evolutionary stages of the MSC in a time span covering approximately 600 Kyr (CIESM, 2008; Clauzon et al., 2015; Roveri et al., 2019) is widely used and promoted in the 


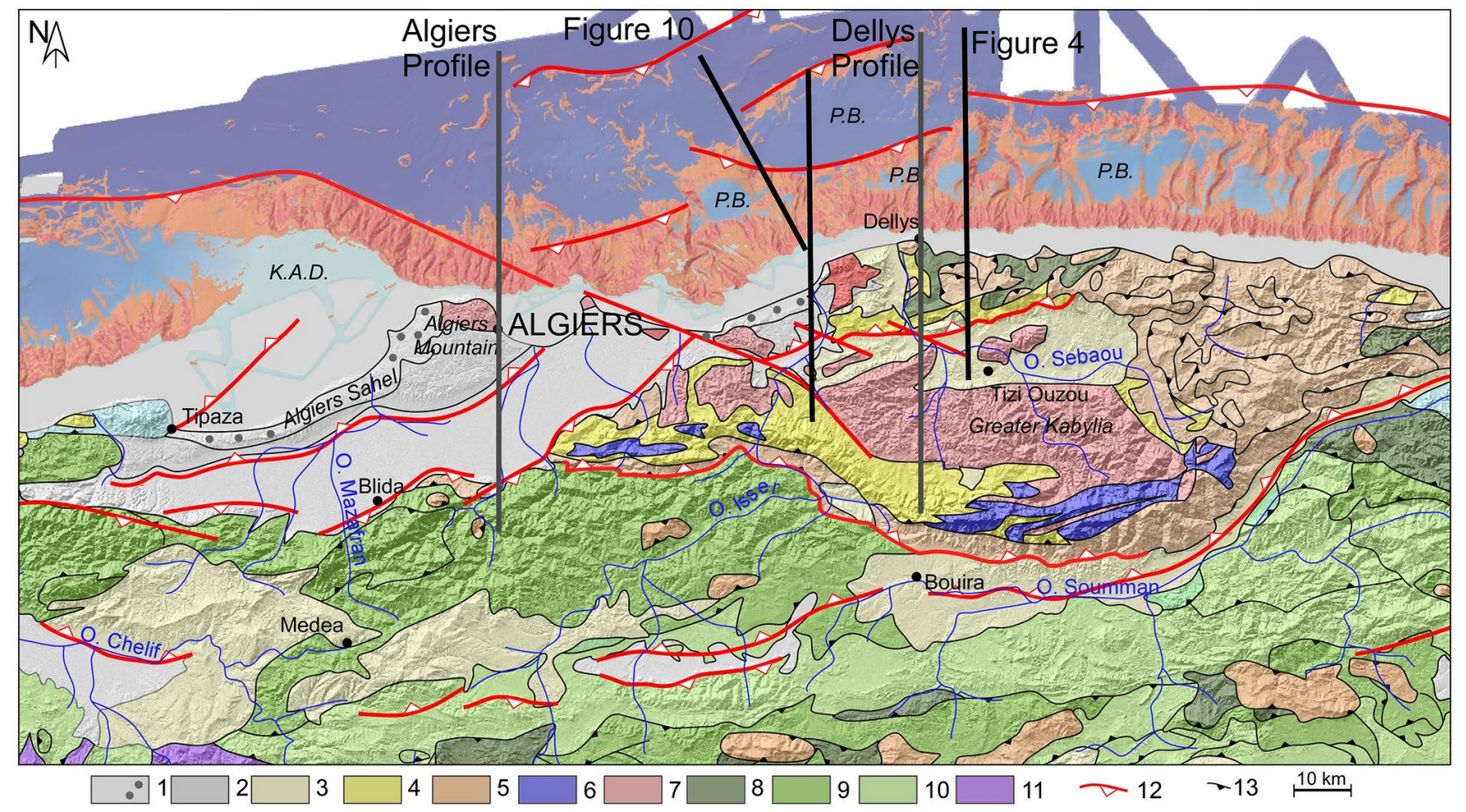

Figure 2. Structural scheme of central-northern Algeria (location in Figure 1). Regional geological map onshore modified after Raymond (1976), and Wildi (1983). Onshore geology: 1: Uplifted beaches, 2: Quaternary deposits, 3: Late Miocene deposits, 4: Early Miocene deposits, 5: Numidian flyschs, 6: Jurassic cover of Kabylia, 7: Kabylian basement, Tellian units (8: lower 9: middle 10: upper) (after Wildi, 1983), 11: Autochthonous units, 12: active faults after Aïte and Gélard (1997), Babonneau et al. (2017), Domzig et al. (2006), and Yelles et al. (2006, 2009), and 13: Miocene faults. P.B., perched Basin. Classified bathymetry offshore modified after Strzerzynski et al. (2010). Shaded DEM after SRTM onshore and MARADJA cruise (http://dx.doi.org/10.17600/5020080) offshore.

international community and matches the available geological and geophysical data. Therefore, although we acknowledge that other hypotheses may exist and could be explored, we have adopted the following simple steps and timing to build the MSC scenario of our experiment: 1 [6.0-5.6 Ma]: formation of marginal basins with minor sea-level fall; 2 [5.6-5.5 Ma]: significant subaerial erosion and sea-level drawdown; and 3 [5.5-5.4 Ma]: sea-level rise and fast reflooding.

\section{Geomorphology, Coastal Uplift, and Strain Rates}

Offshore, the Algerian margin exhibits an unusual morphology compared to the surrounding Mediterranean margins. In central Algeria, the continental slope is characterized by steep scarps of several hundred meters high alternating with perched basins (Dan et al., 2009, 2010; Déverchère et al., 2005; Domzig et al., 2006; Strzerzynski et al., 2010; Figure 2). The continental shelf is very narrow except for a large bathymetric high, called the Khayr al Din Bank or KAD (Figure 3; Domzig et al., 2006; Yelles et al., 2009). Swath bathymetry and seismic profiles acquired after the 2003 Bourmerdès earthquake revealed blind reverse faulting at the base of the margin affecting Plio-Quaternary units and propagating towards the abyssal plain (e.g., Dan-Unterseh et al., 2011; Déverchère et al., 2005; Domzig et al., 2006; Kherroubi et al., 2017; Strzerzynski et al., 2010; Figures 2 and 4).

Onshore, the morphology is characterized by a low but contrasted relief region (maximum altitude of $600 \mathrm{~m}$ ) extending from the seashore up to $25 \mathrm{~km}$ to the south (Figure 1). To the east of Algiers, the coastal domain consists of several hills incised by Isser and Sebaou rivers, while to the west, a flat area called the Mitidja valley is filled by Miocene, Pliocene, and Quaternary deposits (Figures 2 and 3). Further south, relief increases and forms the Greater Kabylia and the Blida Atlas reliefs (maximum altitude $>1,200 \mathrm{~m}$; Figure 3). At the coastline, several uplifted Pliocene/Pleistocene/Holocene marine terraces and rasas have been reported (Authemayou et al., 2017; Heddar et al., 2013; Raymond, 1976). Datings and topographic measurements led the authors to estimate coastal uplift rates well below $0.5 \mathrm{~mm}$.yr- 1 over the last $400 \mathrm{Kyr}$ (Authemayou et al., 2017). Mapping of Pliocene marine deposits highlights the occurrence of perched (>300 m) Messini- 

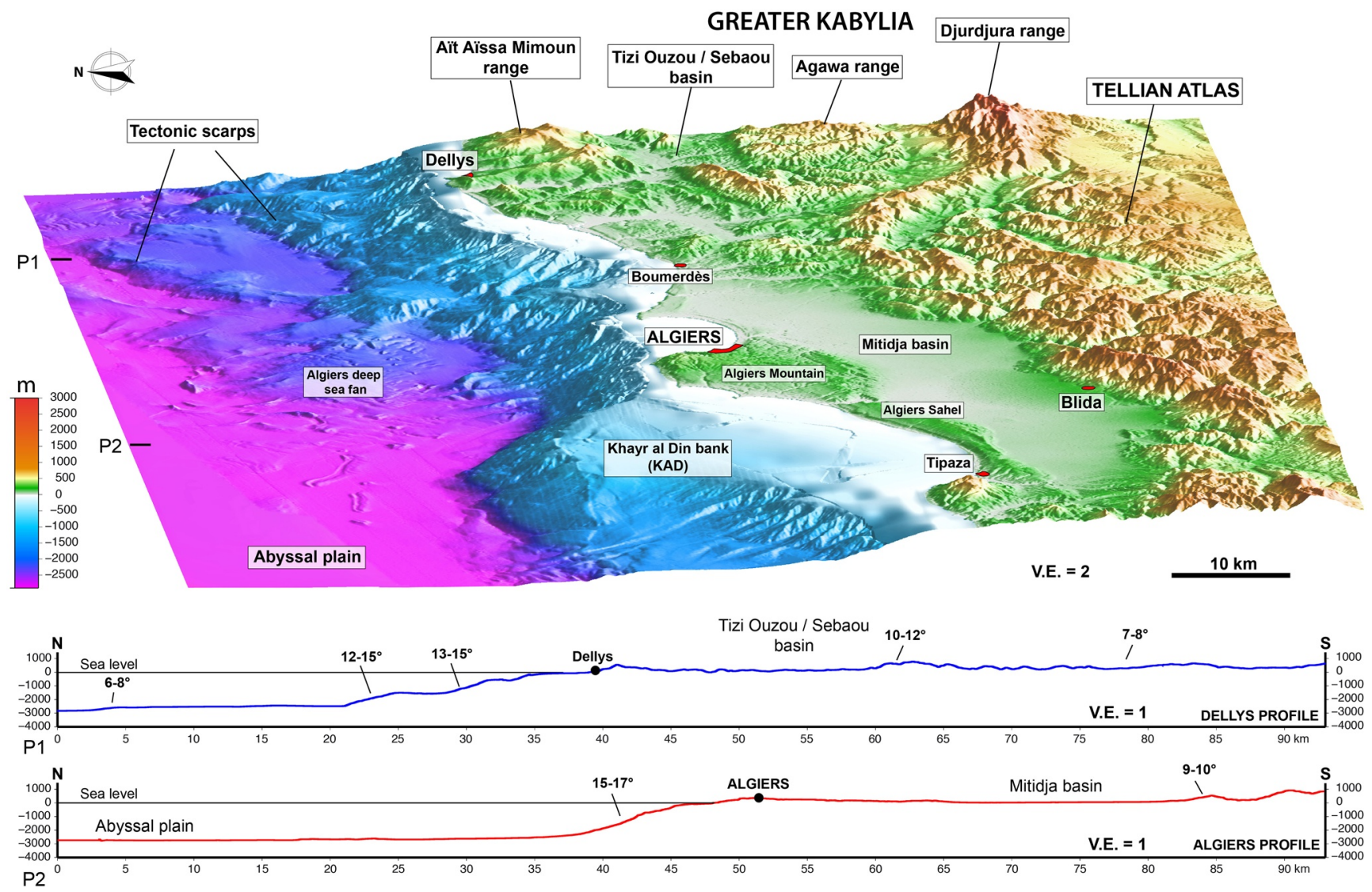

Figure 3. Three-dimensional shaded view toward the East of the central Algerian margin and topographic profiles. See location on Figure 2.

an rias (Figure 2). Even if uplift rates are low when compared to other regions, it has significantly impacted the drainage evolution as evidenced, for example, by the eastward migration of the Isser river bed as a direct consequence of anticline growth on land (Boudiaf et al., 1998) and by a deviation to the west of the Sebaou river (Djemai, 1985).

Finally, recent kinematic studies help us to provide an upper bound of the total amount of margin shortening since Messinian time, a value needed to understand the margin evolution, and to set up our modeling approach. Finite and instantaneous rates between Europe and Africa (Nubia) plates are derived from high-resolution kinematic reconstructions (de Mets et al., 2015) and geodetic measurements (Bougrine et al., 2019; Serpelloni et al., 2007) respectively. Within uncertainties, de Mets et al. (2015) have shown that Nubia-Eurasia motion has been relatively steady during the past $\sim 13 \mathrm{Myr}$, without significant change in motion before or during the MSC, and with a constant $\mathrm{N} 135^{\circ}$ direction of Africa-Eurasia convergence since $\sim 7 \mathrm{Ma}$. At the Algiers longitude, the Africa-Eurasia convergence rates encompassing the whole maghrebian belt, and the margin, range between 4.6 and $6.4 \mathrm{~mm}$ year $^{-1}$. These values overestimate the shortening rates accommodated across the Algerian margin and the coastal domains. On the contrary, the present-day shortening rate found in the offshore part between Algiers and Alicante $\left(1.5 \pm 0.5 \mathrm{~mm}\right.$ year $^{-1}$, Figure 1 ; Bougrine et al., 2019; Serpelloni et al., 2007) does not take into account shortening in the coastal domains and underestimates the shortening rates on the studied area. Therefore, we propose a $2.2 \pm 0.5 \mathrm{~mm}_{\text {year }}^{-1}$ shortening rate for the Algerian margin and the coastal domains at the Algiers longitude. As strain migrates progressively through time from the Maghrebian belt toward the Algerian margin (Recanati et al., 2019), the initial shortening rate of the margin should be lower than present-day estimates. Taking into account all these results, we propose that no more than half of the total Nubia-Eurasia convergence has been accommodated in the studied area (Figure 1), representing possibly $11 \pm 3 \mathrm{~km}$ of cumulated crustal shortening since the Pliocene. 


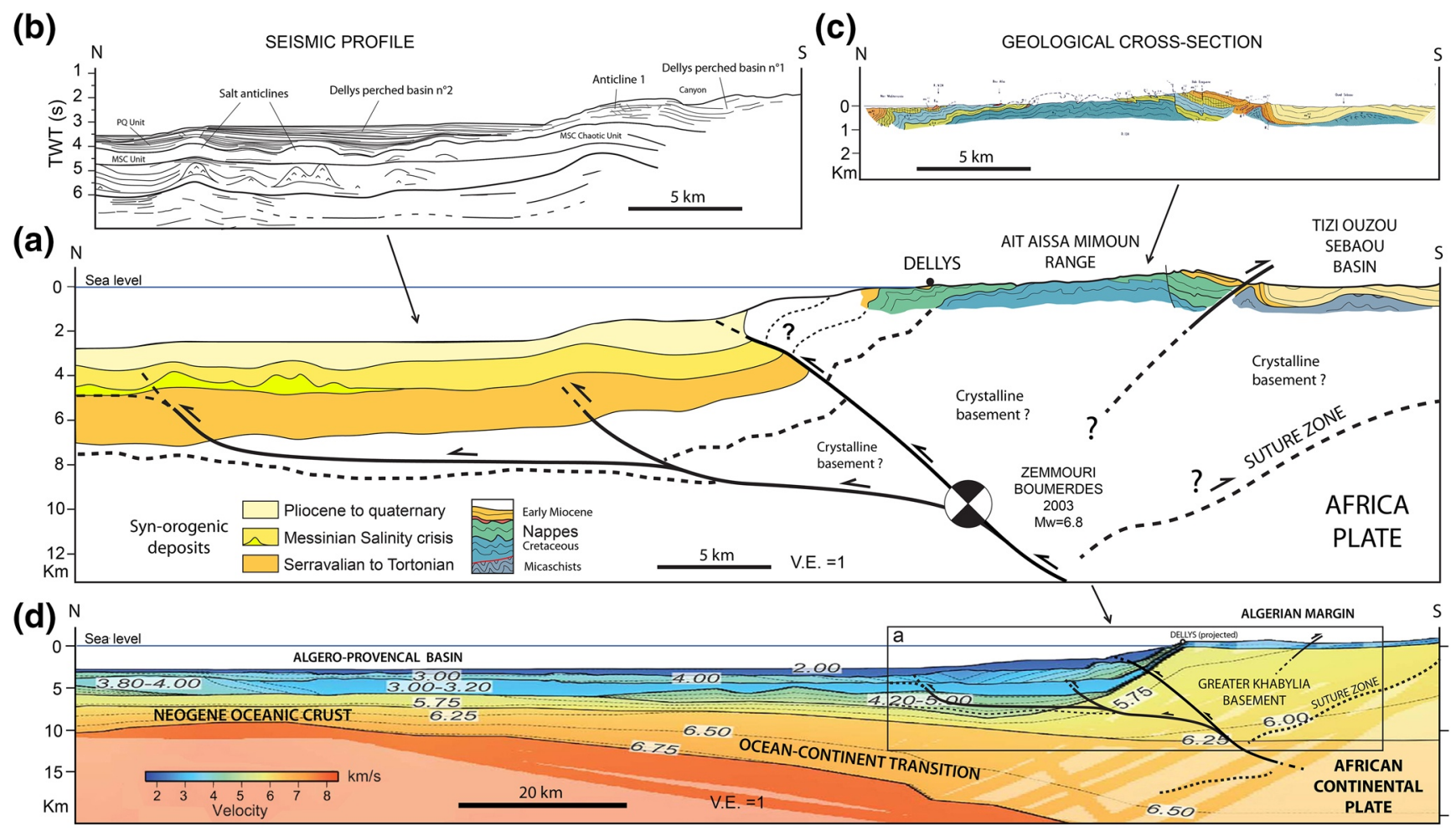

Figure 4. (a) Synthetic cross-section of the Algerian margin at the longitude of Greater Kabylia (see Figure 3 for location) realized after (b) line drawing of Maradja seismic line offshore (Strzerzynski et al., 2010), (c) geologic cross-section on land (Raymond, 1976), and (d) a velocity cross-section based on wide-angle seismic data (Aïdi et al., 2018), with the approximate position of the 2003 Boumerdès-Zemmouri hypocenter and focal solution after Kherroubi et al. (2017).

\section{Geological Evidence for a Tectonic Inversion}

We summarize here several facts and results supporting a significant Plio-Quaternary shortening of the Algerian margin accommodated both on land (Internal units-Tell-Atlas belt) and at sea (Figures 2 and 3; Benaouali-Mebarek et al., 2006; Déverchère et al., 2005; Domzig et al., 2006; Kherroubi et al., 2009; R. Leprêtre et al., 2018; Mauffret, 2007; Strzerzynski et al., 2010; Yelles et al., 2009).

\subsection{Deep Structures and Rheology}

The $M_{w}$ 6.9 May 21, 2003 Boumerdès-Zemmouri event has evidenced a $\sim 55 \mathrm{~km}$ long active reverse fault (strike $\mathrm{N} 70^{\circ}$, dip $40^{\circ} \mathrm{S}$, rake $95^{\circ}$, depth range $2-11 \mathrm{~km}$; Delouis et al., 2004) striking parallel to the coastline (Bounif et al., 2004; Kherroubi et al., 2017). Aftershocks, local tomography, and geodetic measurements show that the earthquake occurred on a south-dipping thrust located at $6-10 \mathrm{~km}$ depth below the shoreline with ramp-flat-ramp systems upward and strong afterslip toward the surface, near the margin toe (Kherroubi et al., 2017; Mahsas et al., 2008) (Figures 1 and 4). From recent wide-angle seismic data, the Moho is found at 20-25 km depth beneath the continental domain, evidencing a relatively thin continental crust over $\sim 60 \mathrm{~km}$ across strike, while toward the Algerian basin, the Moho rises to a depth of about $10 \mathrm{~km}$ and the crust is of oceanic type (Aïdi et al., 2018; Bouyahiaoui et al., 2015; A. Leprêtre et al., 2013). Recent 2D thermo-mechanical models suggest that in the central Algerian margin, both the thinned continental crust and the high geothermal gradient favor strain localization and underthrusting of the oceanic lithosphere at the margin toe (Hamai et al., 2018). Therefore, the rheology of the Algerian margin is likely weak owing to the propagation of the Tethyan slab tear and the Miocene (17-11 Ma) plutonic and volcanic activity emplaced in the Kabylies posterior to the collision (Chazot et al., 2017, and references therein). 


\subsection{Fold-and-Thrust Geometry of the Central Algerian Margin}

Offshore, the Pliocene to present-day deformation is expressed by kilometer-scale wavelength folds located at the foot of the continental slope and in the deep basin (Figures 2 and 3), but also in the upper margin where many slides, active canyons, and gullies mask the cumulated scarps (Dan et al., 2009, 2010; Dan-Unterseh et al., 2011). The area affected by deformations is characterized by a significant seismic activity (Figure 1). The fold asymmetry is compatible with the motion of blind reverse thrust faults dipping toward the continental domain (Figures 2 and 4). Folds interact closely with salt diapirism, hemipelagic sedimentation, and mass-transport deposits, forming complex structures (Dan-Unterseh et al., 2011). The number of reverse faults changes from one place to another along the studied area: only one is present at the foot of the continental slope of the KAD bank, whereas four are identified on the Boumerdès transect where they bound perched (piggy-back) basins (Dan-Unterseh et al., 2011; Déverchère et al., 2005; Domzig et al., 2006). The sedimentary record suggests that the earliest faults are located close to the coastline and then deformation propagated northwards into the deep basin (A. Leprêtre et al., 2013; Strzerzynki et al., 2010). This chronology is in agreement with a tectonic wedge starting to form mostly during Pliocene-Quaternary times (Déverchère et al., 2005; Strzerzynski et al., 2010) and that is still active today (Kherroubi et al., 2017). A décollement level is suggested to develop at the base or in the lower part of the Cenozoic cover (Aïdi et al., 2018; Strzerzynki et al., 2010; Figure 4), while to the south, deformation is rooting in the basement of the Greater Kabylia block (Aïdi et al., 2018; Déverchère et al., 2005; Kherroubi et al., 2017; Figure 4). Also, asymmetric folds compatible with north-dipping reverse faults are found in the upper margin, for instance on the KAD bank (Domzig et al., 2006; A. Leprêtre et al., 2013; Strzerzynski et al., 2010; Yelles et al., 2009; Figures 2 and 3).

Onshore, recent and active reverse faults have been evidenced by the deformation of Quaternary sedimentary units (Authemayou et al., 2017; Boudiaf, 1996; Boudiaf et al., 1999) and earthquake data (Ousadou \& Bezzeghoud, 2019). Two main north-dipping reverse faults are identified in the coastal domain. The most spectacular one can be followed from the cities of Algiers up to Tipaza where it forms a $250 \mathrm{~m}$ topographic high called the Sahel of Algiers (Authemayou et al., 2017; Heddar et al., 2013; Meghraoui, 1991; Figure 2). The fold asymmetry supports a north-dipping reverse fault (or backthrust) located on the southern flank of the fold. Further east, the northern boundary of the Tizzi Ouzou - Sebaou basin (Aïte et Gélard, 1997) is also controlled by a north-dipping thrust (Boudiaf et al., 1998; Figure 2). Uplift of the Algiers massif occurred before the MSC (Authemayou et al., 2017), thus suggesting a possible onset of margin inversion during Tortonian, as proposed by Recanati et al. (2019). However, at least two-thirds of the uplift of this coastal massif occurred since the early Pliocene.

Considering these overall fold-and-thrust geometry and time constraints, we propose that the Central Algerian margin inversion can be modeled as a tectonic wedge characterized by a décollement layer plunging below Africa, with an initial relief decreasing toward the Mediterranean domain and with shortening starting after the MSC. During the experiment, the emerged-submerged device records strong sea-level changes during MSC immediately followed by a slow shortening inversion. The cumulated horizontal shortening does not exceed $11 \pm 3 \mathrm{~km}$ since the Pliocene and the shortening rate is probably increasing through time as the deformation progressively migrates from the onshore to the offshore domains. According to our present-day knowledge of strain history, this tectonic scenario is able to describe reasonably well the sedimentary, erosional, and tectonic evolution of the Algerian margin, at least in its central part.

\section{Experimental Approach}

\subsection{Methodology}

The study of continental margins faces several limiting factors related mainly to the difficulties to image their internal structures, to pass through the seawater barrier which strongly limits direct seafloor observations and rock sampling. The correlation of geophysical and geological measurements acquired on land and at sea with different methods remain also challenging. To overcome part of these limitations, and test the evolutionary scenario that emerged from these data, we modified an experimental approach initially developed to study the interactions between tectonics-erosion-sedimentation (Graveleau \& Dominguez, 2008; Graveleau et al., 2011, 2012, 2015; Guerit et al., 2016; Strak et al., 2011; Villaplana et al., 2015). Previous ex- 


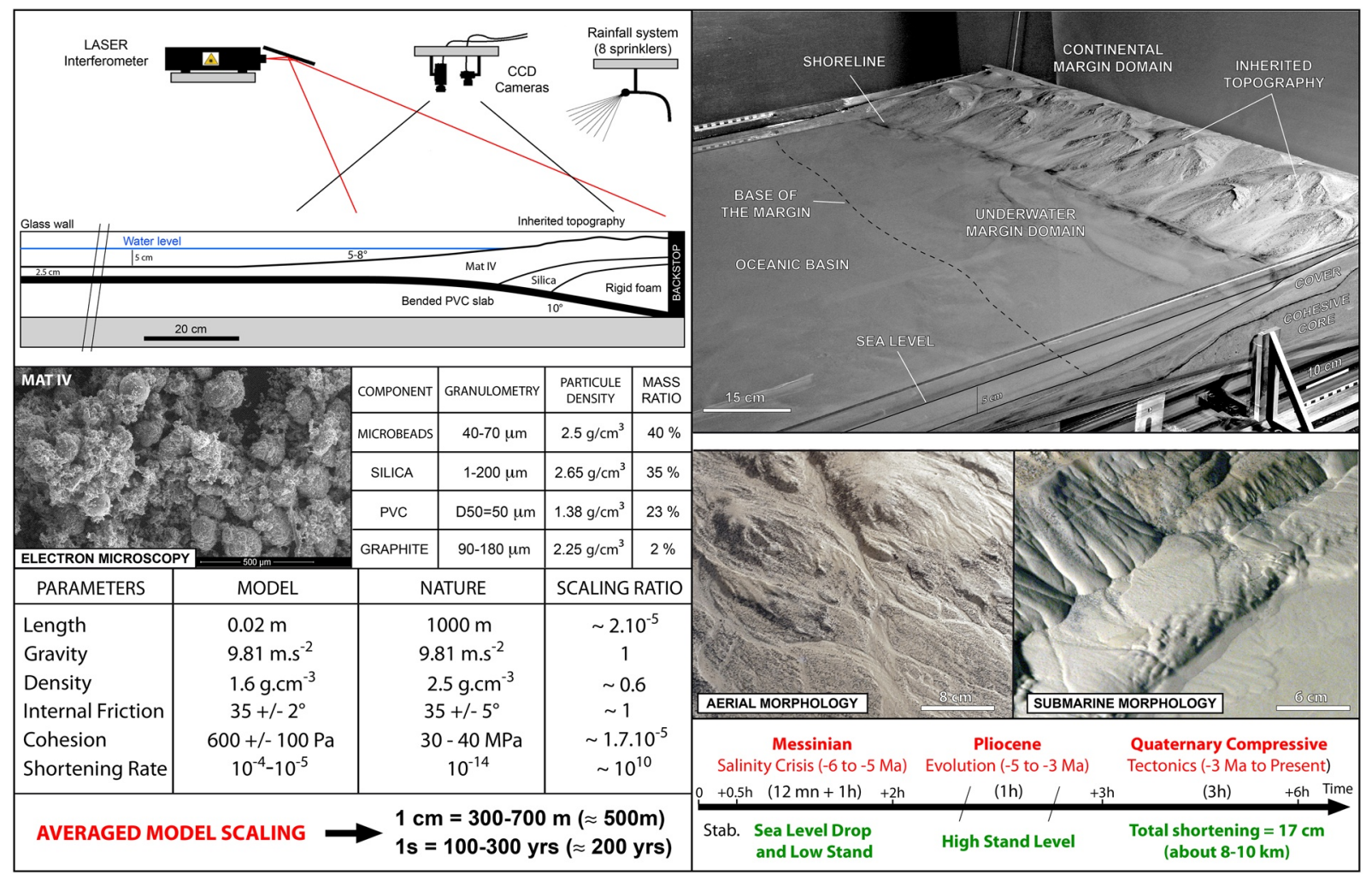

Figure 5. Top left: Experimental setup consisting of a deformation device, a rainfall system, and CCD cameras coupled to a laser interferometer. the MATIV analog material simulates the Meso-Cenozoic sedimentary units. The Silica powder simulates the more resistant Paleozoic basement and magmatic intrusions constituting the core of the Algerian margin. Center left: Physical properties of the analog material. Bottom left: Shortening and sea-level evolution displayed on the timeline of the experiment. Top right: View of the model surface displaying a submerged domain to the left and an emerged domain to the right. Bottom right: Example of aerial and submarine model morphologies.

perimental works have already investigated basin tectonic inversion (e.g., Cerca et al., 2010; Mc Clay, 1989) but without integrating realistic surface processes (erosion, water transport, and sedimentation) as does our approach. This pioneering work represents, then, the first attempt to model experimentally the inversion of a passive continental margin by including on land and offshore domains together with realistic terrestrial and submarine geomorphogenetic processes.

\subsection{Setup and Boundary Conditions}

The experimental set-up used in this study is constituted by a mechanical apparatus to deform the analog model, a rainfall system to erode its surface, and a digital monitoring device used to quantify model evolution during the experiment (Figure 5). The deformation device is made of a $1.5 \mathrm{~m} \times 2.2 \mathrm{~m}$ aluminum structure supporting a $2 \mathrm{~cm}$ thick PVC plate bounded by three glass/PVC walls and a rigid backstop. The PVC plate is bent toward the backstop up to a dip of $10^{\circ}$. A Mylar/carbon sheet, lying on the PVC plate, is pulled beneath the backstop using a computerized stepping motor to impose model shortening. The rainfall system uses up to 8 sprinklers to diffuse water micro-droplets over the model surface at a rate of $25-30 \mathrm{~mm} / \mathrm{h}$ (Figure 5). Water runoff enhances erosion of the emerged part of the model (coastal domain) triggering several natural processes shaping the topography such as; channel incision in the drainage network, slope diffusion, and gravity-controlled landslides. In the submarine part of the model, sedimentation processes dominate but gravity-driven instabilities also contribute to shaping the submarine morphology. The digital monitoring device is constituted by a laser interferometer coupled to CCD cameras to measure deformation kinematics and model topography during the experiment. The digital elevation models have typical spatial resolution and precision of 3-5 and 1-2 mm, respectively. The subpixel spectral correlation technique is 
used to quantify fault kinematics with a submillimeter precision (Graveleau et al., 2011; Strak et al., 2011). At the end of each experiment, model cross-sections are performed to study its internal structure.

\subsection{Analog Materials}

To model jointly onshore and offshore fluvio-deltaic sedimentary systems, we used the analog material developed by Graveleau and Dominguez (2008), Graveleau et al. (2011), and modified by Strak et al. (2011). This material was initially designed to study tectonic-erosion interactions in active mountain forelands and along normal fault scarps (Figure 5). Analog material composition was only slightly modified mainly to adapt its cohesion to model scaling requirements (see Section 5.4). The analog material used in this study is composed of $40 \%$ of glass microbeads, $35 \%$ of silica powder, $23 \%$ of plastic (PVC) powder, and $2 \%$ of graphite powder (Figure 5). We use a PVC powder and glass microbeads with smaller grain sizes compare to Graveleau's experiments to decrease the bulk granulometry of the mixture and increase the transport distances of the eroded particles. The analog material mechanical properties were measured using a direct shear test apparatus for average water saturation of $20 \pm 1 \%$. Internal friction and cohesion are respectively: $\varphi=35 \pm 2^{\circ}, \mathrm{Co}=600 \pm 100 \mathrm{~Pa}$. During the experiment, water run-off induces water oversaturation on the first millimeters of the model which drastically decreases the cohesion (Co $<$ a few tens of Pa) favoring, then, model surface erosion. Density and median grain size of the analog material are $\mathrm{d}=1.6 \pm 0.1 \mathrm{~g} / \mathrm{cm}^{3}$, $\mathrm{D} 50=80 \pm 5 \mu \mathrm{m}$. Erodability properties of the analog material are close to those of the mixture used by Graveleau and Dominguez (2011) and were measured using the same methodology. The innermost part of the model was made using a wedge-shape rigid foam covered by a high cohesive material to simulate the more resistant Algerian margin crystalline basement (Greater Kabylia and related basement blocks). This proto-backstop was also designed to smooth the sharp mechanical transition between the deformable analog material and the rigid vertical backstop which limits the rear part of the experimental device (Figure 5).

\subsection{Analog Model Scaling}

As demonstrated by several authors (Cobbold \& Jackson, 1992; Davy and Cobbold, 1991; Hubbert, 1937, 1991; Richard, 1991; Schellart \& Strak, 2016; Shemenda, 1983), analog model scaling can be achieved using several proportionality ratios between model and nature physical and mechanical parameters. Specifically, an analog model is properly scaled if geometric, kinematic, and dynamic similarity criteria are fulfilled. Inertial forces can be neglected in nature at the geological time scale as well as in our experiments, slow deformation rates are imposed on the model $\left(10^{-4}\right.$ to $\left.10^{-5} \mathrm{~s}^{-1}\right)$. Considering that upper crustal rocks and granular analog materials deform according to the Mohr-Coulomb failure criterion, the similarity criteria to be considered are:

$$
\begin{gathered}
L^{*}=L m / L n \text { for the geometric criterion } \\
S^{*}=C o^{*}=d^{*} \cdot g^{*} \cdot L^{*} \text { for the dynamic criterion }
\end{gathered}
$$

$L^{*}, S^{*}, C o^{*}, d^{*}$, and $g^{*}$ are model to nature ratios for length, stress, cohesion, density, and gravity, respectively. Lm and Ln are characteristic lengths in models and nature, respectively.

To study a characteristic portion of the Algerian margin evolution, we considered that it was necessary to model a $>50 \mathrm{~km}$ wide portion of the margin. Considering the maximum achievable model size using the experimental device, we imposed a spatial scaling of $1 \mathrm{~cm}=500 \mathrm{~m}$, close to the values used by Graveleau et al. (2011) and Strak et al. (2011). For natural sedimentary rocks, internal friction and cohesion values typically range between 20 and 40 and 10-60 MPa, respectively (Byerlee, 1978; Hoek \& Brown, 2019; Lama and Vutukuri, 1978). According to the scaling theory, the internal friction coefficient of the analog material should be equivalent to those of natural rock. Considering the mean density of the analog material mixture $\left(1,600 \mathrm{~kg} / \mathrm{m}^{3}\right)$, a mean natural sediment density of $\sim 2,500 \mathrm{~kg} / \mathrm{m}^{3}$, a mean natural rock cohesion of $\sim 30-40 \mathrm{MPa}$, a mean length ratio of $L^{*}=2.5 \times 10^{-5}$ and using Equations 1 and 2, we calculate that the analog material should have a mean cohesion of about 500-600 Pa. We, then, adapted the composition of 
the analog material, by changing the proportion of microbeads versus silica powder, to approach the required values $\left(\varphi=35 \pm 2^{\circ}, C o=600 \pm 100 \mathrm{~Pa}\right)$. Note that, at the short time-scale, and as discussed in Paola et al. (2009), a rigorous scaling of the dynamic criterion is not possible; for instance, the water used to erode the model has a too high kinematic viscosity to be compatible with the Reynolds dimensionless variable. However, the Froude number is less affected by this discrepancy and appears to be similar in Nature and our analog models (from 0.2 to 0.6 and from 0.01 to 1 , respectively) indicating that the long-term dynamics behavior of natural rivers is properly simulated.

Evaluating time scaling is a difficult task because the morpho-tectonic processes (e.g., fault slip, fluvial incision, sediment transport, and hillslope processes) that shape natural and modeled topographies occur over several orders of velocities. Achievable time scaling requires also to neglect inertial forces, which would not be possible if we aimed at reproducing the short-term behavior of natural material and fluid flows. In our experiments, fluid flows can locally produce small accelerations but their impact on model morphology remains negligible. Therefore, we considered that accelerations are small enough to neglect inertial forces. Based on these considerations, we propose a simplified solution where time scaling can be reasonably estimated by comparing long-term erosion rates in the models and Nature. To achieve this goal, we use two similarity criteria that include time and velocity (e.g., Hubbert, 1937):

$$
\begin{gathered}
T^{*}=T m / T n \text { for the kinematic criterion } \\
V^{*}=V m / V n=(L m / T m) /(L n / T n)=L^{*} / T^{*} \text { for the similarity of velocities }
\end{gathered}
$$

$T^{*}$ and $V^{*}$ are model to nature ratios for time and velocity, respectively. $T m$ and $T n$ are characteristic times in models and nature, respectively. $V m$ and $V n$ are velocities in models and nature, respectively.

In our experiments, we measure the catchment-averaged denudation rate ranging from 1 to $5 \mathrm{~mm} / \mathrm{h}$. In nature, catchment-averaged denudation rates typically range between 0.5 to a few $\mathrm{mm} / \mathrm{year}$ in active tectonic contexts (e.g., Stock et al., 2009; Tucker et al., 2011). Using these values and Equation 4, it results that $1 \mathrm{~s}$ of model evolution can be compared to about 100-300 years in Nature. Based on these considerations, to simulate $6 \mathrm{Myr}$ of model evolution, the experiment should last about 6-10 h, and the MSC stage, about 1 hour (Figure 5).

For such complex models, time scaling cannot be achieved rigorously and should be nonetheless used as a first-order estimation considering the limits of the scaling theory and the uncertainties on natural rocks and analog material physical parameters.

\section{Experimental Results}

\subsection{Initial Conditions}

At the initial stage, the geometry of the analog model should match the morphology of the Algerian margin just before the MSC at $-6 \mathrm{Myr}$. At that time, the margin is assumed to correspond to a "classic" young passive margin not yet affected by tectonic inversion (see e.g., R. Leprêtre et al., 2018 and Sections 2-4). Its internal structure is inherited from the rifting associated with the back-arc extension induced by the Tethyan slab rollback during Miocene (van Hinsbergen et al., 2020, and references therein). Because no other reliable information is available, the initial geometry of the model is defined as a simple wedge dipping seaward at a slow angle (Figure 5). Close to the backstop, the model is $25 \mathrm{~cm}$ thick, then, its thickness decreases progressively, following the $10^{\circ}$ dipping PVC basal plate to reach $2 \mathrm{~cm}$ at $75 \mathrm{~cm}$ on the right side of the model and $100 \mathrm{~cm}$ on the left side. The slight lateral variation of the margin slope angle $\left(5^{\circ}-7^{\circ}\right)$ was designed to take into account the non-cylindrical shape of the present Algerian margin morphology (Figure 1). Seaward, the mylar sheet is covered by $2-3 \mathrm{~cm}$ of analog material to represent the Neogene ( $>$ Langhian) marine sediments deposited in the Algerian basin. The water level is maintained constant during the experiment at $4-5 \mathrm{~cm}$ over the seabed so, at the initial stage, about $4 / 5$ of the model surface is submerged and corresponds to the marine domain and $1 / 5$ is emerged and corresponds to the continental (coastal) 
domain. To accelerate drainage network initiation, long-wavelength $(>20 \mathrm{~cm})$ and low amplitude $(<2 \mathrm{~cm})$ reliefs are randomly manually shaped on the emerged part of the model.

During the first hour of the experiment, the sea-level is maintained stable, the rainfall system is turned on to let the model topography slightly evolve and reach a static equilibrium SUP MAT. VIDEO/TIMELAPSE 1). The model morphology evolved to a point where the water run-off cannot generate basal shear stress strong enough to erode the model surface. Rivers neither incise nor aggrade, and the topography remains stable over the long-term.

During this period, a small amount of erosion is observed on the emerged domain and sediment deposits start to form at the river mouth (Figure 6-1). The geometry of these seaward prograding deposits is characterized by the association of two distinct slopes forming a wedge-shaped unit: near the shoreline, sediment deposits, and river mouth slopes are subhorizontal. About one centimeter seaward, the slope abruptly increases to a higher angle around $25-30^{\circ}$ high. The internal structure of the deposits is dominated by layering dipping seaward and parallel to the steepest slope and compatible with downlap in nature. Within these deposits, the four components of the material IV appear sorted: from the top to the base of the wedge, silicate powder, glass microbeads, PVC powder, and graphite powder. These characteristics are comparable to those of deltaic bodies in nature.

\subsection{Sea-Level Fall - Low Stand and Rise}

To simulate erosion, transport, and deposition of detritic materials during the MSC, we impose to the model a fast and huge sea-level fall (12 $\mathrm{mn}$ and $3.5 \mathrm{~cm}$, respectively) followed by a longer ( $60 \mathrm{mn}$ ) low stand period.

The sea-level fall leads to the progressive exposure of the uppermost margin cover and coastal deposits (Figures 6-2, 7, and 8-1). Subjected to rainfall, most of these materials are rapidly eroded, through debris flows like processes, and deposited few centimeters downslope as they reach the new seashore position. Such a process occurs continuously as the sea-level continues to fall. At the end of the sea-level fall, most of the upper margin cover has been eroded and a network of channels and submarine fans has formed. Incision processes are not yet very marked on the exposed margin and the continental domain. At this time, we add manually a thin layer $(1 \mathrm{~cm})$ of microbeads on the whole abyssal plain surface to simulate the deposition of the deep evaporite layer (MU for Mobile Unit, see Lofi, Déverchère, et al., 2011; Lofi, Sage, et al., 2011). This induces an increase of the base level without an increase in subsidence.

During the low stand period, low amplitude $(<1 \mathrm{~cm})$ sea-level oscillations are simulated to reproduce the inferred intermittent sea-water supply that could be, at least partly, at the origin of the huge evaporite unit and investigate their impact on the sedimentation processes. The fluctuation of the river mouth base level favors the progradation into the basin of well-stratified alluvial fans deposits, interacting with the previous large chaotic debris flows, over the evaporite layer (Figures 6-3, 7, and 8-2). At the same time, on the emerged part of the margin, the drainage network gets denser and some canyons are growing. Regressive erosion propagates upslope into the continental domain, widening and re-incising rivers, and pre-existing valleys (Figure 7).

The end of the low stand sea-level and the flooding are here considered as instantaneous, therefore during this stage, the rainfall system is switched off to "freeze" the model morphologic evolution and to mimic the end of the MSC.

\subsection{Initial Inversion of the Margin}

After the flooding, the rainfall system is turned on and surface processes resume in absence of tectonics. During that stage, due to the rise of the channel/river base level, incision on the emerged domain is inhibited. The river mouths of the valleys, incised during the low stand sea level, are progressively filled by deposits that compare to gilbert-type deltas. Erosion on the submerged domain is at this time relatively limited (Figures 7-4 and 8). After $30 \mathrm{mn}$, the model surface stops evolving significantly, meaning that it has reached an equilibrium. Indeed, in the absence of tectonics and sea-level changes, the model morphology 


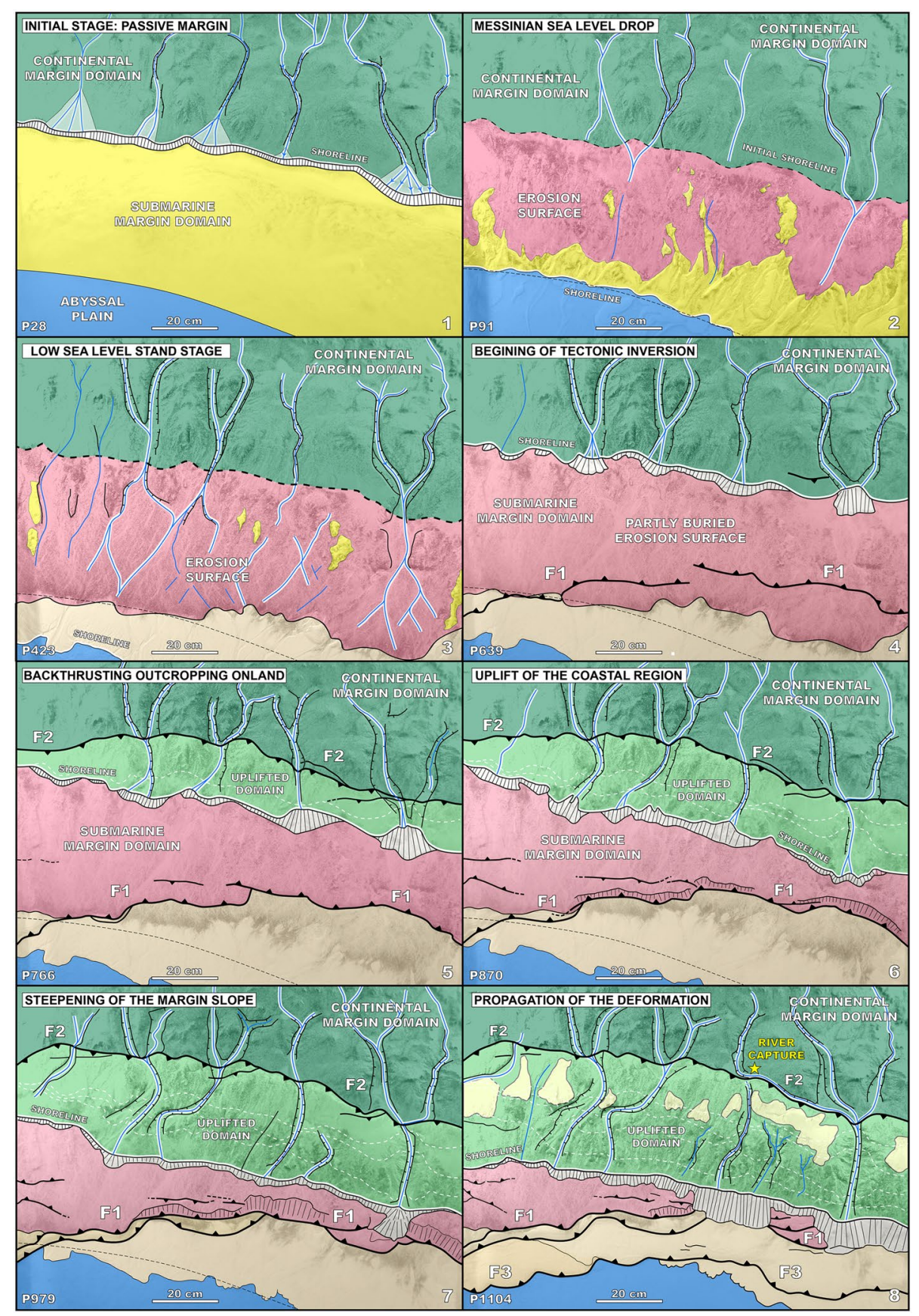

Figure 6. Upper views of the model surface (left) and interpretations during the main steps of the experiments. 1: initial stage; 2: end of the sea-level drawdown; 3: end of the sea-level low stand and deposition of the deep salt layer; 4, 5, 6, and 7: first margin inversion step; 8: final stage—second margin inversion step (see text for explanations + SUP MAT. VIDEO/TIMELAPSE 1).

doesn't evolve anymore. Sediment transports in the channels are strongly reduced and hill-slope erosional processes almost ceased.

Compressive deformation is then applied to the model, starting with a shortening rate of $3 \mathrm{~cm} \mathrm{~h}^{-1}$, increasing up to $6 \mathrm{~cm} \mathrm{~h}^{-1} 90 \mathrm{mn}$ later and finally to $12 \mathrm{~cm} \mathrm{~h}^{-1} 30 \mathrm{~min}$ before the end of the experiment to simulate a progressive transfer of the tectonic plate convergence to the margins and coastal domain. After $45 \mathrm{mn}$ 

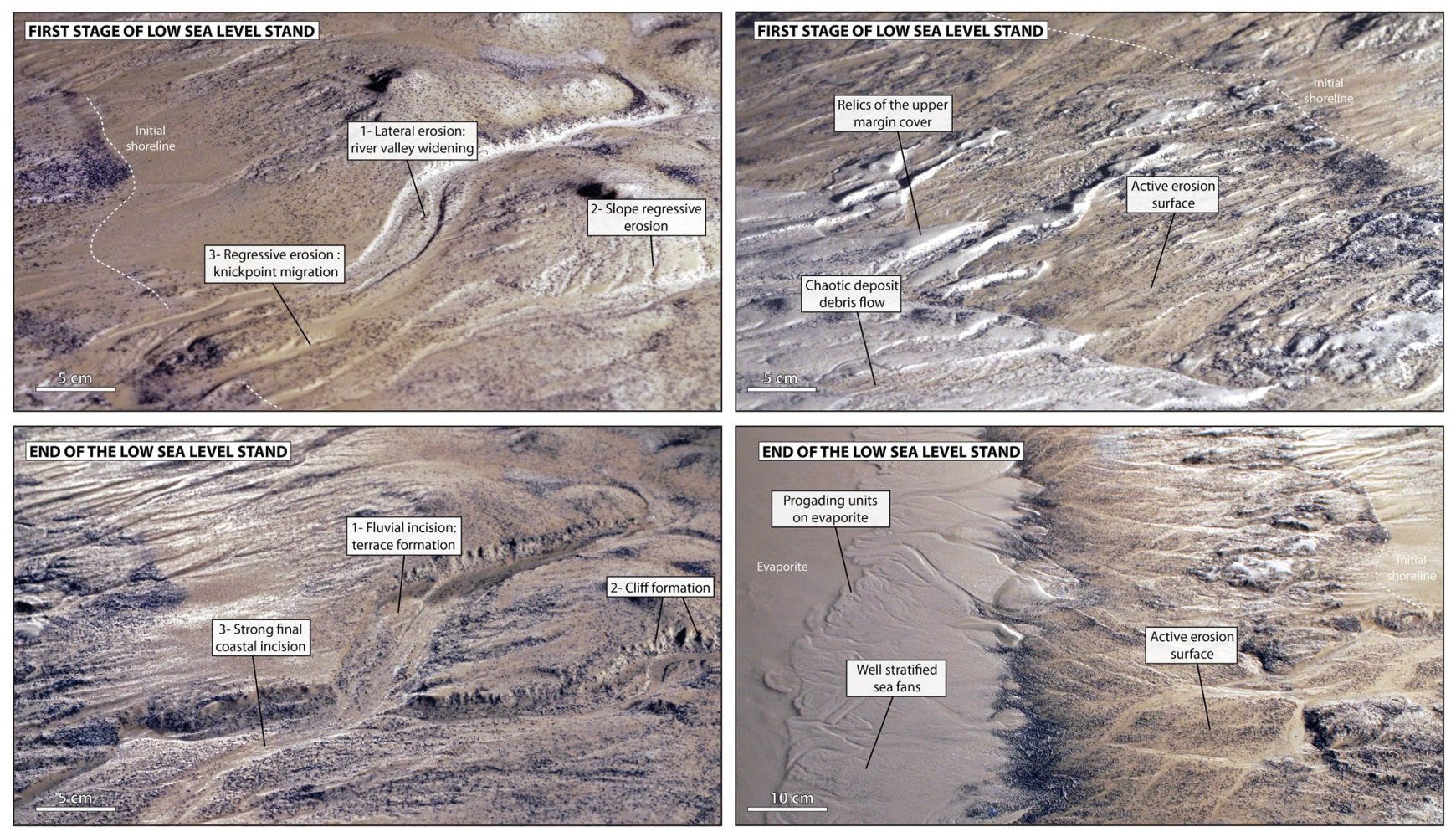

Figure 7. Example of morphologic markers associated with the Low Stand Sea-level stage (LSSL), corresponding to Stage 2 of the MSC (5.6-5.5 Ma) on the upper part of the margin (left) and at its base (right). See the text for details.

and $2.25 \mathrm{~cm}$ of shortening, a first submarine reverses fault (F1), dipping landward at a low angle, initiates at mid-slope in the right part of the model. It propagates towards the left, reaching the base of the margin. At this stage, the fault system F1 appears segmented but it rapidly evolves to form a unique major thrust fault extending along the entire width of the model (Figure 6-4 and 6-5, Video: since 00:01:33). At depth, it follows the top of the bent PVC plate and finally roots at depth below the rigid foam backstop, representing the northern extension of the Kabylian block. The fault F1 accommodates most of the convergence during $15 \mathrm{mn}$ before the birth, on land, of a new reverse fault (backthrust F2) dipping seaward and running parallel to the shoreline, about 15-30 cm centimeters landward (Figure 6-5 and 6-6). As for the fault F1, the F2 fault trace initiates in the right part of the model and rapidly propagates toward the left, cutting almost orthogonally all the rivers connected with the shoreline. Such a propagation directivity is mostly due to changes along the strike of the initial margin wedge geometry and surface slope (see Section 6.1). Landward of F2 fault trace and up to the rigid backstop, the continental domain appears stable and undeformed. In this region, the compressive stress remains probably high enough to consider that the deformation could have propagated landward if the rear part of the model (continental domain) was longer. The activity of fault systems F1 and F2 last $165 \mathrm{mn}$ during which the emersion of the coastal region accelerates. Meanwhile, the thrust system F1 continues accommodating about 2/3 of the crustal shortening (Supplementary Material: Video since 00:01:43).

The onset of compression triggers a new erosional phase and fluvial incision all along the uplifted portion of the upper margin. Once the activity of the coastal faults ends with the birth of the F3 fault, regressive erosion of rivers is no longer compensated by thrusting, inducing reorganization of the river network near the onshore fault (Figure 6-6 and 6-7). The river network is strongly perturbed and forced to re-organize through river captures and deviation processes. The formation of wind gaps is also commonly observed. In response to coastal uplift and folding, the shoreline continuously migrates seaward (Figure 6-5, 6-6, and 6-7; video: since 00:02:27). The former deltaic deposits are quickly eroded and the wedge progrades under forced regressive conditions (Figure 6-6, 6-7). On the right part of the model, progradation leads the delta 


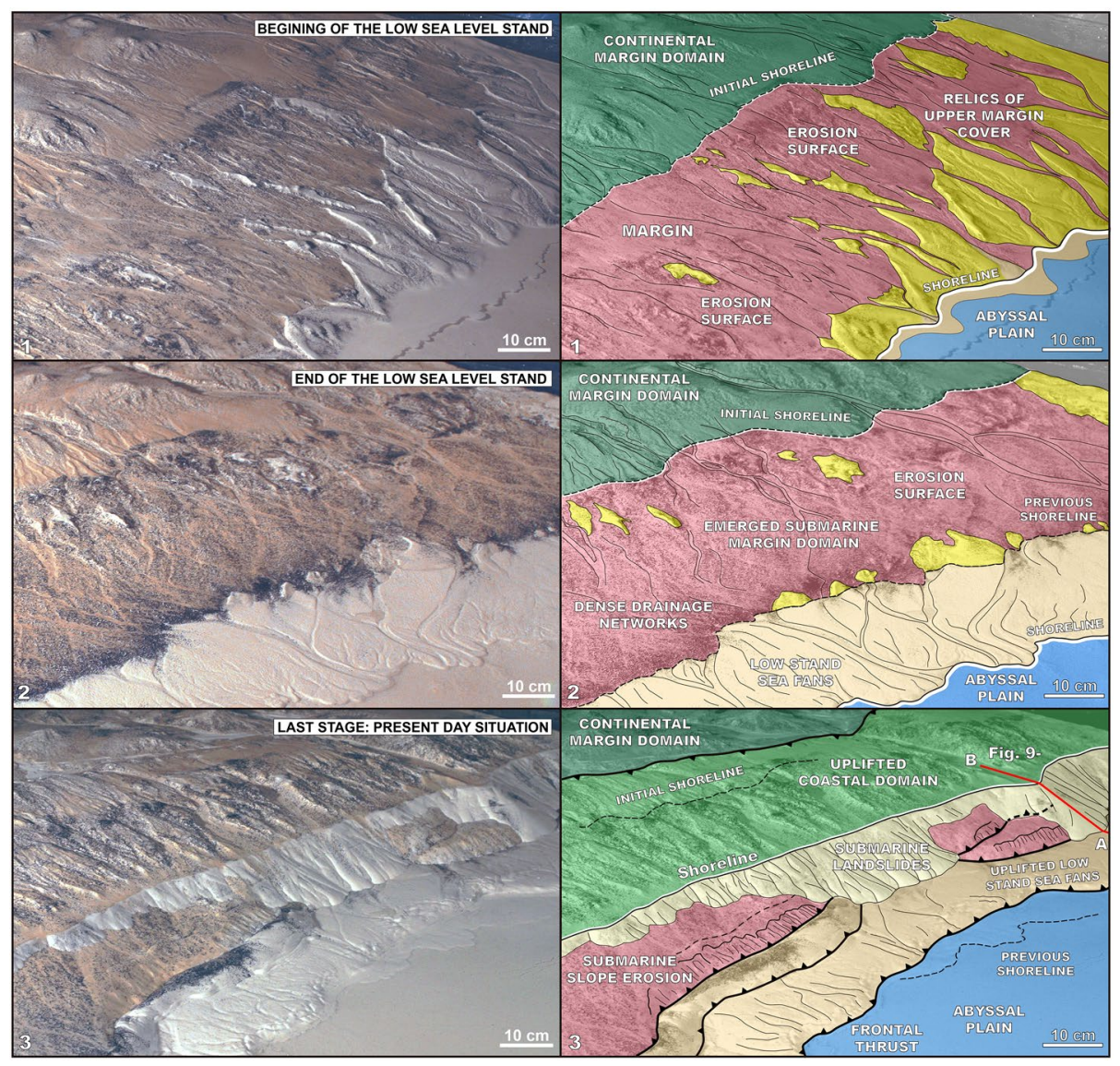

Figure 8. Perspective views of the model surface (left) and interpretations (right) during (1) beginning of the sea-level drawdown (eq. picture 2 on Figure 6), (2) end of the sea-level low stand (eq. picture 3 on Figure 6), and (3) final stage (eq. picture 8 on Figure 6). For each picture, water is removed, however, the shoreline is shown on the interpretation.

wedge to reach and cover the F1 fault scarp (Figure 6-6) inducing a simplified underwater slope with only a limited low angle near the shoreline located at the top of a $4 \mathrm{~cm}$ high scarp dipping downslope (Figure 6-7).

\subsection{Propagation of the Shortening Into the Deep Basin}

About $180 \mathrm{mn}$ after the onset of shortening, the conjugated activity of the submarine thrust system F1 and the on-land backthrust F2 led to a significant shortening of the margin and a strong steepening of the submarine slope, up to $50 \%$ and $30^{\circ}$, respectively (Figures 6, 4 and 7). The margin slope reaches a critical taper and triggers submarine landslides to cover fault scarps. Then, the deformation starts to propagate into the abyssal plain. A new submarine thrust system (F3) initiates seaward of F1, straddling the low stand deposits and the deep part of the basin (Figures 7-8 and 8-3) and forming a piggy-back basin. From this stage, the accommodation of the shortening is mainly accommodated by F1 and F3 thrust fault systems. The migration of the shoreline shows that the margin is still uplifting but at a much slower rate. On land, the decrease of F2 activity and associated coastal uplift induce a last and brief reorganization of the drainage network, triggering some river captures at the footwall of F2 (Figure 6-8). Then, the tectonic activity in the coastal region almost ceases, the shoreline stabilizes and the erosion rate drastically decreases (Supplementary Material: Video: since 00:02:46).

Offshore, the area limited by F1 and F3 thrust fault systems uplift and evolve as a perched basin up to the end of the experiment (Figures 7-8 and 8-3). Along the F1 fault scarp, growing deltaic wedges interacting with active submarine landslides are still observed. 


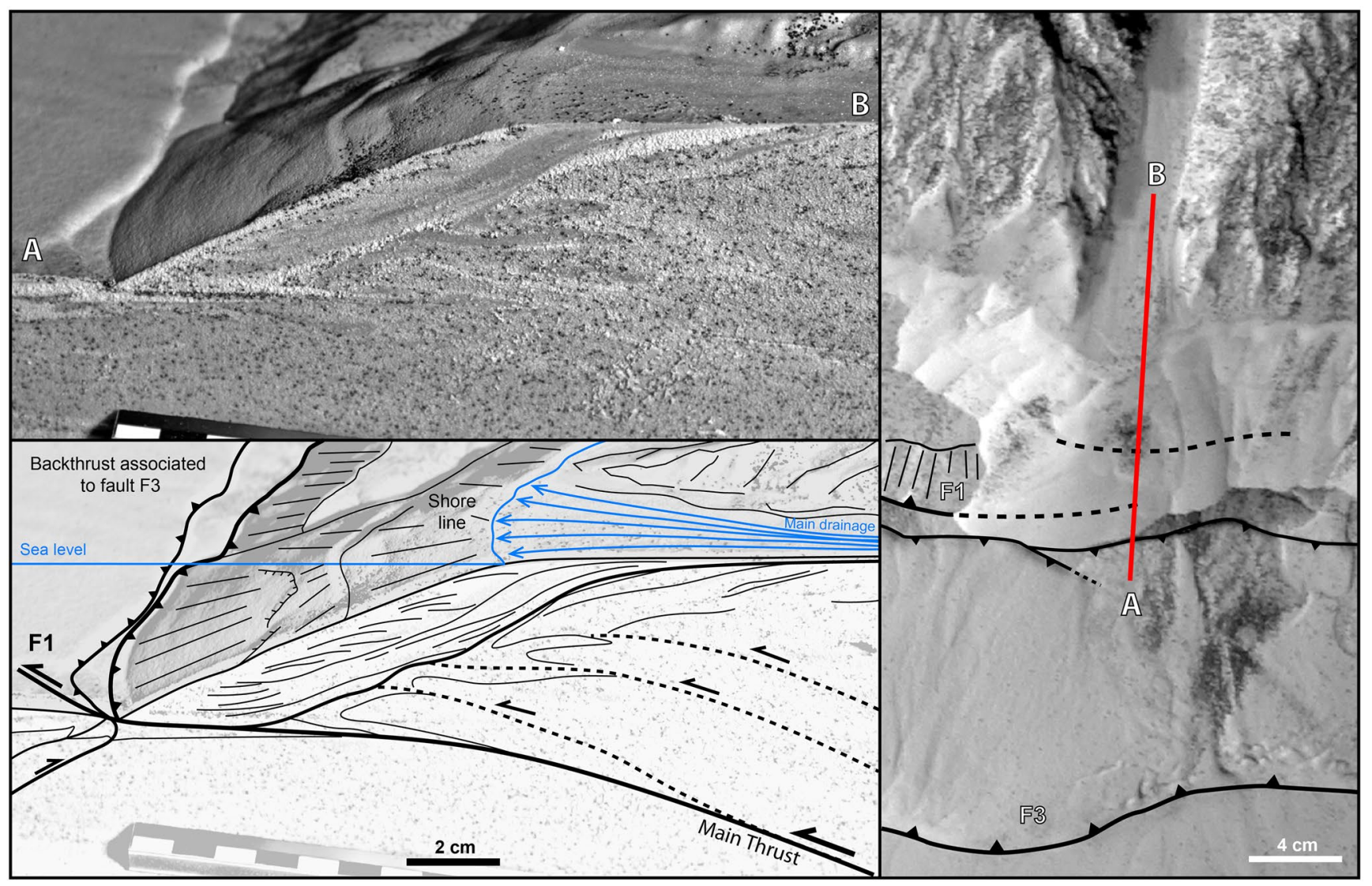

Figure 9. Picture (top) and interpretation (bottom) of a cross-section (right) performed at the end of the experiment through the main drainage displaying the complex association of thrusts at depth, erosion left to the shoreline, and deposition of foresets below sea level.

\section{Discussion}

\subsection{Match of the Model to Marine and Coastal Post-Messinian Evolution}

Up to now, most geomorphic analog modeling focused on the interplay between tectonic and surface processes in continental settings (Graveleau \& Dominguez, 2008; Graveleau \& Dominguez, 2011; Graveleau et al., 2011; Malavieille, 2010; Schellart \& Strak, 2016; Strak et al., 2011). Our study explores for the first time the joint modeling of emerged and submarine domains, paving the way to the study of sea-land tectonic and morphogenetic interactions. In this study, we have identified and analyzed in detail three main types of coupling: the transport processes and material flow between both domains (source to sink), the impact of sea-level variations, and the mechanical tectonic couplings between offshore and onshore domains. We briefly discuss our main findings for each process.

\subsubsection{Sediment Transport and Flow}

In the submerged domain, deposition processes dominate upon erosion processes. As the river flow is stopped down in the marine domain, transported detritic material is deposited near the shoreline at the river mouth (Figures 7-9). Eroded mat IV is here sorted such as silica powder particles are deposited first, followed by glass microbead and then PVC and graphite powders. Note that the smaller particles $(<10 \mathrm{mi}-$ crons) are transported at greater distances through hyperpycnal flow processes and deposit by gravity far from the river mouth. Interestingly, the organization of the main deposits on the slope is characterized by two successive systems of seaward dipping foresets or chaotic units forming several fan-like units (Figures 8 and 10) that are very similar to the two main fluvio-deltaic sedimentary systems emplaced at the margin toe and on the slope during and after the MSC, namely, the chaotic and bedded units (chaotic Unit CU and Bedded Unit BU, almost synchronous to the deposition of salt layer MU and related to Messinian fluvial 

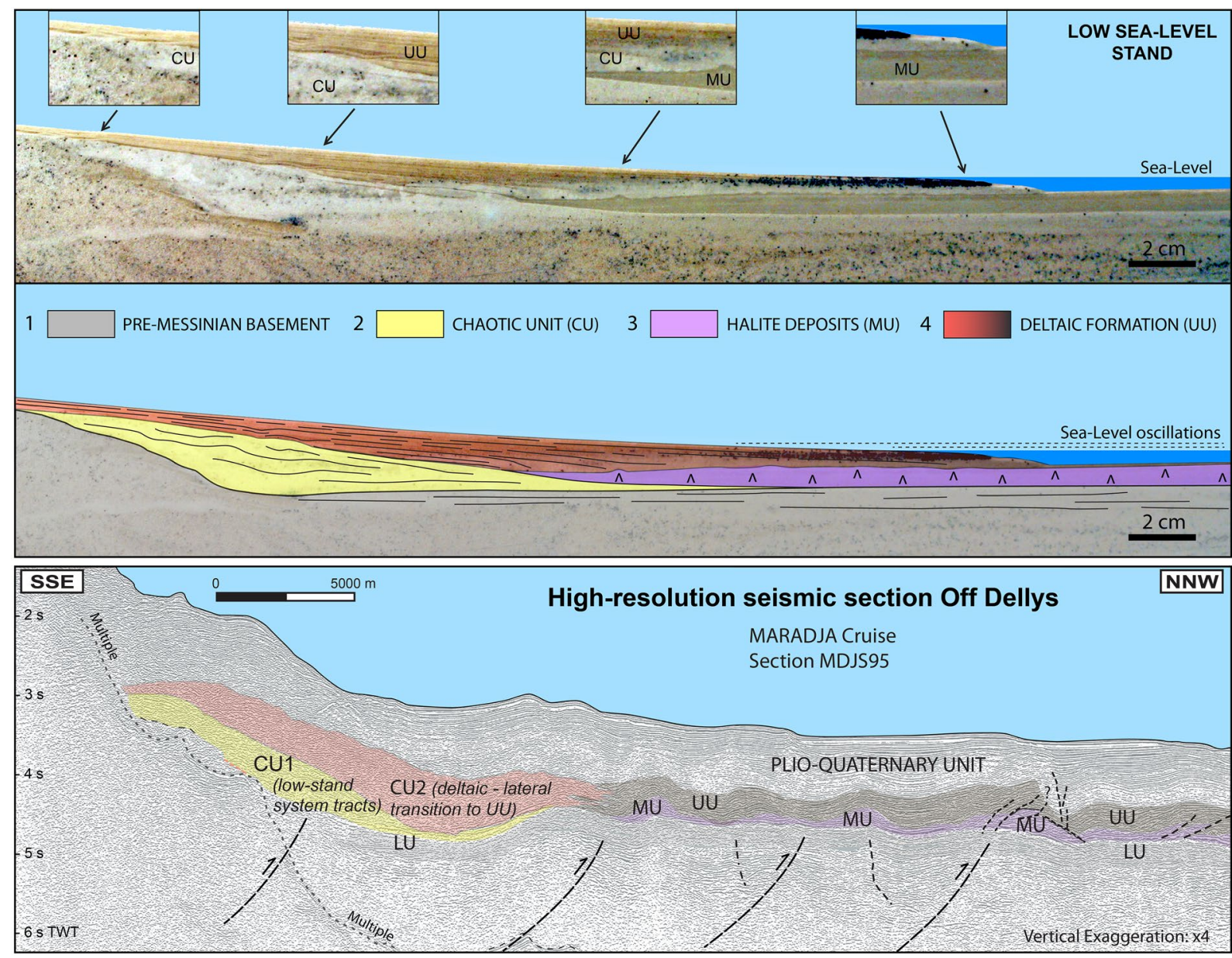

Figure 10. Picture (top) and interpretation (middle) of a cross-section performed at the end of the analog experiment through MSC deposits, in the lower margin and deep basin. 1: basement; 2: chaotic bodies (CU for Chaotic Unit) deposited during sea-level drawdown during Stage 2 of the MSC and related to Messinian fluvial systems (Lofi, Sage, et al., 2011); 3: microbeads manually deposited at the end of the sea-level drawdown, aiming at reproducing the halite deposition (MU) at the beginning of Stage 2 of the MSC; 4: well-sorted deltaic formation deposited during the sea-level low-stand, at the end of the MSC (Stage 3), featuring the last part of CU and at least part of the high-amplitude Upper Unit UU identified in the deep offshore of the Western Mediterranean Sea (Lofi, Déverchère, et al., 2011; Lofi, Sage, et al., 2011). Stages refer to the time periods of the MSC proposed by Roveri et al. (2019) by onshore-offshore correlation of sedimentary successions. Bottom: for comparison, time seismic section interpreted off the central Algerian margin (location on Figure 2), modified from Lofi, Sage, et al. (2011), showing that the angular relationships between sedimentary units are similar to the model, although the salt layer MU underwent significant diapirism and the late tectonic inversion has induced post-deposition folding and faulting.

systems; Figure 4) and the Plio-Quaternary unit, respectively (Lofi, Déverchère, et al., 2011; Lofi, Sage, et al., 2011; Strzerzynski et al., 2010). Furthermore, the imposed low sea-level fluctuations during the low stand period perfectly manage to reproduce the internal structure of the deep Upper Unit UU (Lofi, Sage, et al., 2011), thus providing a convincing succession of depositional events. The widest fan with a low angle foreset and the best internal organization has been obtained during high sea-level (Figure 9).

\subsubsection{Sea-Level Fluctuations}

Along the coastal region, the sea domain defines the base level of the river network. In the context of a sea-level drop or tectonic uplift, rivers record strong regressive erosion (Figure 6-4). The upstream migration of knickpoints has been observed during the MSC low stand sea-level (Supplementary Material: Video: 00:00:09 to 00:00:40 and). It takes several minutes in the experiment until the knickpoints, generated by the sea-level drop, reach the boundaries of the drainage basin. Later, as sea-level increases, the lower part of valleys becomes invaded by the marine domain forming analogs of natural rias such as the Mitidja valley (Rubino \& Clauzon, 2008; Rubino et al., 2005). As a consequence, river incision capacity is then strongly reduced (Figure 7-4). As in the case of land rivers, the evolution of deltas is closely related to the relative sea 
level. During sea-level decrease or tectonic uplift, deltas are migrating seaward, the foreset angle becomes higher, and the internal organization of the fan, more chaotic (Figures 8 and 9). Higher foreset angle and more chaotic internal structures are the results of the quick migration of the marine deposits downslope, erosion of the emerged part of the deltas, and landsliding on the delta's slope. This results in a new mixing (reworking) of the previously sorted materials (Figures 8 and 9). At the end of the sea-level low stand stage, instantaneous sea-level rise induced an instantaneous migration of the fan upslope.

All these observations of fan migration relative to sea-level change and/or tectonic uplift are at first order in good agreement with the principles of sequential stratigraphy and transport processes from an emerged to submerged domains (e.g., Vail et al., 1977) and with the succession or syn- and post-MSC depositional history in the Western Mediterranean Sea (Lofi, Déverchère, et al., 2011; Lofi, Sage, et al., 2011). Furthermore, sorting of material and preservation of layering is directly coupled with sea-level stability and deposition environment: fans related to fast sea-level drawdown are more chaotic than fans growing during a slow vertical motion related to tectonic uplift.

\subsubsection{Interactions Between Submarine and Inland Tectonics}

Soon after the initiation of model shortening, a long-wavelength diffuse deformation affecting both the margin and the continental domains is observed. The model experiences a generalized buckling inducing compressional stress at its front and subsurface dilatancy along a central axial region. Accordingly, the coastal domain starts to uplift at a slow rate and the frontal margin slope to slightly tilt seaward (video: since 00:01:20). This transitional phase of deformation is related to compaction of the model and ends with the initiation of thrust F1, soon followed by the development of a back-thrust F2 (Figure 11).

The two conjugated fault systems F1 and F2 form the boundaries of a large popup structure straddling the shoreline. Because the initial margin shape evolves from one side of the model to the other, the popup is wider to the left and the uplifted region includes a large part of the underwater margin whereas it affects more the upper part of the margin and continental domain to the right. There is a good agreement between the size of the popups in the model $(40-60 \mathrm{~cm})$ and nature $(30-50 \mathrm{~km})$ suggesting that faults root at a depth similar to $20-30 \mathrm{~cm}$ in nature. The competition between F1 and F2 activity appears to control the general kinematics of the uplifted region and, more specifically, the uplift rate of the coastal domain.

The generalized erosion affecting the coastal domain initiates sediment flow toward the sea which intensity is controlled by the interaction between the uplift and erosion rates imposed by active fault kinematics and the rainfall system, respectively. It can be noted that the removal of material on the hanging-wall of backthrust F2 locally decreases the normal stress, contributing, then, to slightly extending its activity through time.

The seaward propagation of the deformation into the deep sea basin, illustrated by the initiation of thrust F3 (and thrust F1' in a first stage), sign a major re-organization of crustal shortening accommodation across the margin. Thrust F1 slip rate decreases by 50 percent while F2 back thrust activity rapidly decreases toward zero. After a few tens of minutes, thrust F3 accommodates alone close to 70 percent of model shortening. This transfer of the deformation to the more external part of the model indicates that the growing accretionary wedge has reached a dynamic state of equilibrium. Consequently, tectonic activity in the upper part of the margin and coastal domain strongly decreased and depicts very slow strain rates today, in good agreement with observations of Quaternary faulting (Authemayou et al., 2017; Heddar et al., 2013) and GPS measurements (Bougrine et al., 2019). Only residual uplift and shortening are reported, probably related to deep underthrusting processes, and the shoreline position tends to stabilize.

\subsection{Modeling the Effects of the MSC}

For the experiment, we have imposed a $3.5 \mathrm{~cm}$ high and $12 \mathrm{mn}$ long water drawdown to simulate a 1,500 $\mathrm{m}$ high sea-level fall which is assumed to have lasted about $150 \mathrm{Kyr}$ in Nature. Although these values may change according to the scenarios chosen, they are, to first order, in agreement with drawdown amplitude and duration generally assumed for the MSC and represent here upper bounds (CIESM, 2008; Clauzon et al., 1996, 2015; Gautier et al., 1994; Lofi, Déverchère, et al., 2011; Lofi, Sage, et al., 2011; Roveri et al., 2019; Ryan, 2011). 

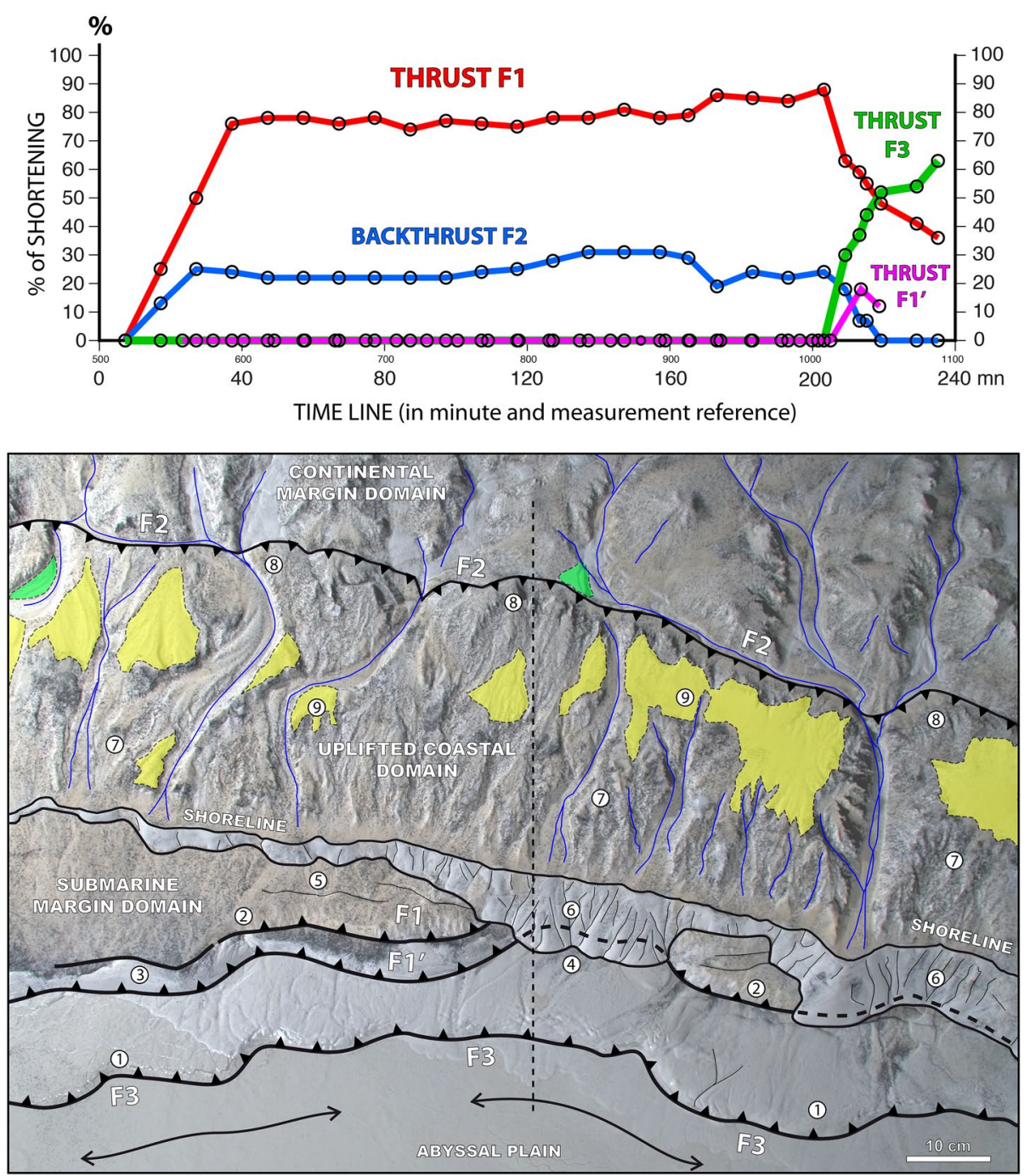

Figure 11. Top: Kinematics of fault systems F1, F2, F3, and F1' as illustrated by the proportion of shortening accommodated through time. Bottom: Fault map showing the main thrust fault systems. The dotted line shows the location of the fault kinematic analysis.

Offshore, the first evidence of the sea-level drawdown is associated with the migration of detritic deposits without any well-developed internal layering down to the foot of the continental slope. Similar complex units (CU) have been observed in an equivalent position all along the Mediterranean margin and interpreted as deep (and coarse?) detrital fans at the foot of the continental slope during the MSC (e.g., Lofi et al., 2005; Lofi, Déverchère, et al., 2011; Lofi, Sage, et al., 2011; Sage et al., 2005; Figure 4). This event has also produced in the upper margins a generalized erosional surface (MES) that is also well developed in the model as channel incision in the drainage network, slope diffusion, and regressive erosion (Figure 6). It is also well recognized that at the MSC onset and during the first stage of sea-level drop (marginal basin stage 1, 6.0-5.6 Ma), gravity slidings and flows are resulting from the early sea-level drop (Lofi et al., 2005) but maybe also to margin steepening due to the weight of brines in the basin (Govers et al., 2009; Ryan, 2011), which is also what is observed in our experiment as soon as the sea-level drop is triggered.

During the sea-level low stand, detritic bodies with a better organization are deposited over the previous fans and the analog of the halite layer MU. This observation suggests that detritic bodies formed during 
and after the sea-level drawdown have a different shape and internal organization. Two different Messinian complexes units have indeed been distinguished in the Algiers area at the margin toe (Lofi, Déverchère, et al., 2011; Lofi, Sage, et al., 2011), the oldest one being coeval with the deposition of salt and the youngest one with the MSC Upper Unit. The timing and the position of detritic deposits found in nature and our modeling thus agrees with a scenario of drawdown ending after the precipitation of the thick halite layer and characterized by two erosion surfaces of different origins, the first one (stage 1) occurring at the end of the primary evaporites deposition in marginal settings, and the second one (stage 2) during a major sea-level fall (Clauzon et al., 1996; Ryan, 2011). Glacio-eustatic changes during these stages (Hodell et al., 2001) could have favored sea-water supply, salt thickening and progradation or layering of deep units CU1 and CU2 (Figure 10). Note that since deep basin subsidence is not simulated in the analog model, some related sedimentary processes are not reproduced.

On land, the model highlights the propagation of a wave of regressive erosion upslope, re-incising pre-existing rivers and valleys. On the Algerian shore, similar Messinian paleo-valleys are identified (from west to east, the Cheliff, Algiers, and Soumman incised canyons): the Messinian valleys are transformed into rias infilled by large Pliocene deltas which are nowadays found on land owing to the progressive coastal uplift (Authemayou et al., 2017; Rubino \& Clauzon, 2008; Rubino et al., 2005; Figure 3).

\subsection{A Two-Step Algerian Margin Inversion}

\subsubsection{Early Fault Pattern, Popup Structure, and Coastal Uplift}

\subsubsection{Faulting}

The first shortening phase of the model is characterized by the formation of conjugate reverse faults located both onshore and offshore. Offshore, faults are located in the middle of the slope and at the foot of the margin and are dipping landward below the northern extension of the Kabylian block, as testified by marine studies (Aïdi et al., 2018; Déverchère et al., 2005; A. Leprêtre et al., 2013; Strzerzynki et al., 2010; Yelles et al., 2009). Onshore, deformation occurs only along one main north-dipping thrust located close to the Messinian shoreline (a few tens of centimeters at the end of the experiment (i.e., ca. 10-20 km on the field), in agreement with similar active reverse faults reported in Greater Kabylia (Aïte and Gélard., 1997; Boudiaf et al., 1998; Figures 2 and 4) and in the Sahel of Algiers (Authemayou et al., 2017; Heddar et al., 2013; Meghraoui, 1991; Figure 2). These faults form the boundaries of a popup structure located on both sides of the shoreline/coastal domain. In our study area, a very similar popup structure is observed (Figures 1 and 2), especially in the area of the KAD bank where a unique thrust is observed offshore, at the foot of the continental slope, and where a low-rate present-day tectonic activity is reported in the coastal domain (Sahel Fault: Authemayou et al., 2017; Heddar et al., 2013; Yelles et al., 2009).

\subsubsection{Surface Processes}

As a consequence of the popup growth, both model and nature provide evidence for a coastal uplift, seaward migration of the shoreline, and emersion of a part of the margin. Offshore, model evolution (Figure 8), and cross-sections of the final stage (Figure 10) highlight the strong mobility of detritic deposits: newly deposited materials upslope are quickly emerged and later on eroded, transported, and resedimented downslope. Consequently, only foresets are built and indeed preserved in nature (Déverchère et al., 2010; Strzerzynski et al., 2010; Yelles et al., 2009) and the model (Figure 10), confirming the lack of available space for the deposition of aggradational beds on the shelf. Onshore, the $>10 \mathrm{~km}$ wavelength uplift is associated with the model with the progressive emersion of the top of the margin. Strong erosion processes quickly destroy all previous deposits and later affect the basement (Supplementary Material: Video: from the beginning to 00:00:10). River incision increases and favors the formation of abandoned terraces in the model, which is indeed reported in the coastal domain of central Algeria, especially in areas located between the coastline and the coastal faults (west: Sahel fault, Heddar et al., 2013; Authemayou et al., 2017; east: the northern boundary of the Tizzi Ouzou - Sebaou basin; Boudiaf, 1996). Uplifted beaches are here preserved from erosion (Figure 2). 


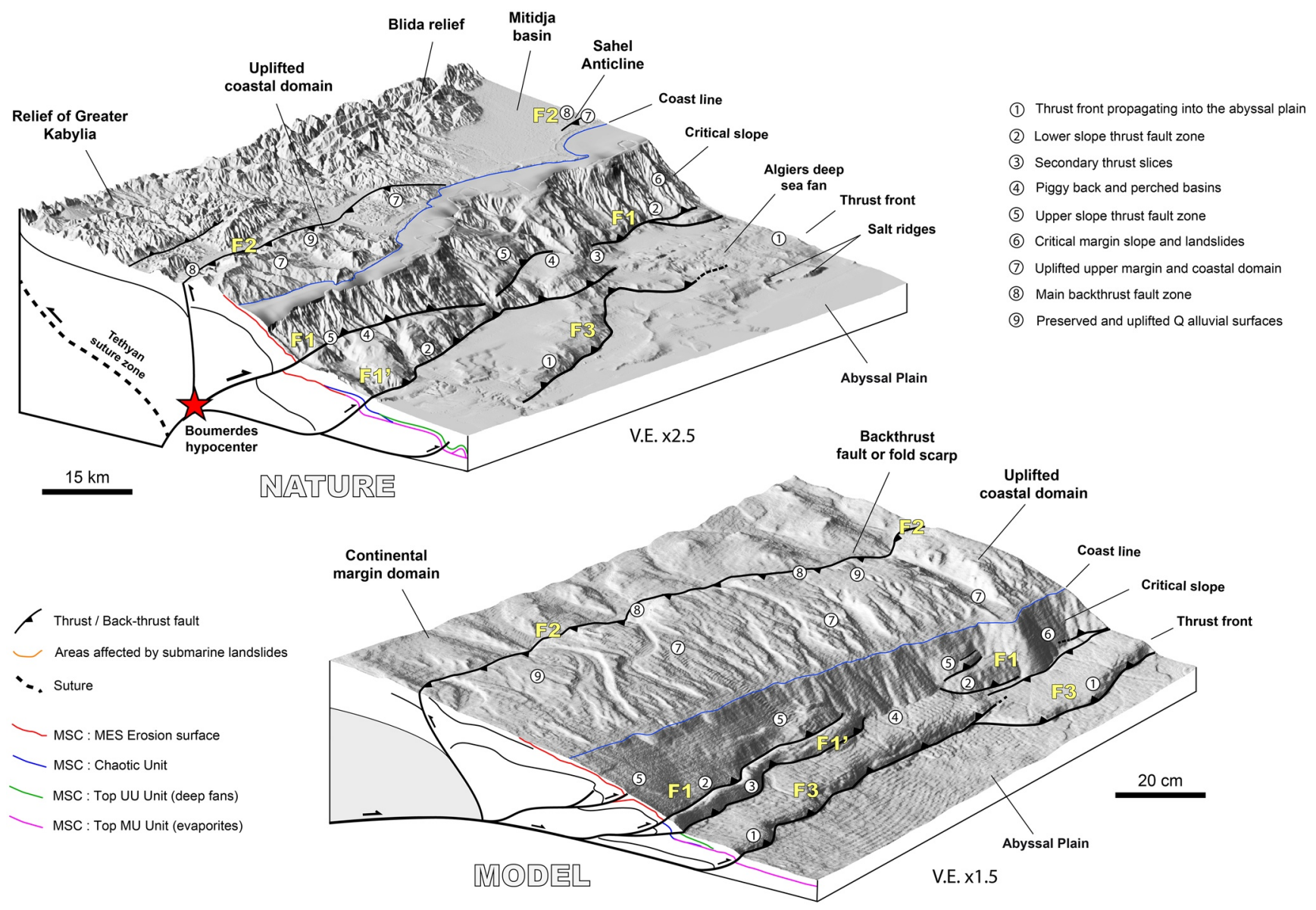

Figure 12. Comparison of the tectonic and morphological features between the final stage of the model (bottom) and central Algerian margin (top). The similar structures are labeled from offshore to onshore (north to south): (1) landward dipping thrust faults bounding perched (piggy-back) basins formed during the margin inversion stage $2 ;(2,3,4,5,6)$ landward dipping thrust faults and blind thrust faults (5) bounding perched basins on the continental slope (stage 1 ); (7) emerged part of the uplifted margin; (8) backthrust; (9) uplifted alluvial surface. Pink surfaces are the main zones of sedimentation in perched basins on the slope and deep basin.

\subsubsection{Submarine Tectonic Wedge Growth and Drainage Evolution}

A major second step of the inversion in the model is characterized by the birth of a new fault (F3) propagating into the deep basin, while the backthrust F2 becomes inactive and Thrust F3 strongly decreases its activity (Figure 11). The F3 fault forms the seaward boundary of a perched (piggyback) basin. Similar fault pattern and perched basins have been reported especially off the Boumerdès and Dellys areas (Figure 2-4 and Figure 12; Déverchère et al., 2005; Domzig et al., 2006; Strzerzynski et al., 2010). During this late stage (Quaternary), the uplift of the margin continues, at a much slower rate, both in the model and in nature, implying that crustal material is incorporated at the base of the wedge by underthrusting (Figures 8 and 9). The eastern part of the Algiers area is the only place where river changes related to tectonic processes have been evidenced (Boudiaf et al., 1998; Djemai, 1985; Figure 4). Similarly, this is also the only place where deformation propagates into the deep basin and reaches the surface (Dan-Unterseh et al., 2011; Domzig et al., 2006, Strzerzynski et al., 2010; Figures 2 and 3). This suggests that river changes in this area may have been the direct consequence of the propagation of the deformation and the initiation of a tectonic wedge in the deep basin, while strain rates on the coastal faults or within Greater Kabylia become very low, as supported by continuous GPS measurements (Bougrine et al., 2019). 


\subsubsection{Thin-Skinned or Thick-Skinned Tectonics?}

Our wedge model is based on the assumption of the occurrence of a décollement layer located beneath the margin and dipping below the margin. Although such a structure has been only indirectly suggested as crustal flat-ramp systems by seismic studies (Aïdi et al., 2018; Déverchère et al., 2005; Roure et al., 2012), the existence of a crustal decoupling layer in the lower crust of the stretched continental margin is supported by the $M_{w} 6.92003$ Boumerdès-Zemmouri earthquake source location and aftershock sequence (Kherroubi et al., 2017). Many fold-and-thrust belts worldwide depict a similar style of thick-skinned tectonics (Pfiffner, 2017). Whether the decoupling layer in the lower crust propagates outward as a décollement layer at the top of the basement (Figure 4) is not demonstrated. Whatever the case, the overall geometry of the thrust system in our case study is similar to the outward propagation modeled in numerical experiments where successive thick-skinned thrusts emerging from the crust drive thin-skinned detachment of the sedimentary pile (Erdös et al., 2014; Pfiffner, 2017).

\section{Concluding Remarks}

Analog modeling coupling sedimentation, erosion, and tectonic inversion of a passive continental margin have provided numerous similarities with the Algerian margin regarding the structural and sedimentary pattern and the surface processes (Figure 12).

First, our simulation of sea-level oscillations during the MSC leads to destruction and re-sedimentation of deposits from the upper slope to the abyssal plain. In the lower margin, the sedimentary succession comprises first, chaotic bodies as the sea-level drawdown and second, well-sorted (deltaic) deposits during the sea-level low stand, whereas in the upper margin, a large erosional surface with a dense drainage network are ultimately covered by large deltas and hemipelagic deposits. A sea-level fall and rise of ca. 1,500 m appears to match both in space and time the succession of the main depositional and erosional events, the latter being underlined by the upstream migration of knickpoints within rivers.

Second, our experiments highlight a two-stage inversion of the margin in agreement with the tectono-sedimentary evolution of the central Algerian margin, characterized by the birth and growth of (1) a large popup structure subparallel to the coastline onshore and (2) piggy-back basins offshore. Our results provide the frame to interpret the south-dipping Boumerdès-Zemmouri earthquake rupture plane as an in-sequence thrust (F1 in the model), the coastal fault system as an out-of-sequence thrust (F2), and the Pliocene to present-day tectonic structures as prograding in-sequence thrusts (F3). These results support the early development of a thick-skinned/thin-skinned tectonic style within less than 5 Myr preceding a process of subduction inception. Although the onset of margin inversion may have started during Tortonian times, the main stages of the sedimentary, erosional, and morphological evolution of the central Algerian margin can be explained by a significant Post-Messinian tectonic shortening at rates less than $2 \mathrm{~mm} / \mathrm{year}$ and exhumation (uplift) at rates less than $0.5 \mathrm{~mm} /$ year. The a posteriori comparison of the overall geometry and finite deformation between nature and our preferred model (Figure 12) supports the hypothesis that in the inversion process, the pre-Messinian deformation is a smaller order of magnitude compared to post-Messinian deformation.

Finally, our modeling shows that the growth of a large popup structure (F1 and F2 faults), and later of the F3 fault outward, which takes over F1 and F2 in a late-stage, strongly influences drainage and depositional patterns. For instance, the comparison of our modeling and the study area (Figure 12) evidences the development of hinterland and foreland catchments, the abandonment or persistence of antecedent rivers, deflected drainages, laterally propagating structures, and aggradation in piggyback basins, which are all typical features formed where growing folds interact with coeval depositional systems (Burbank et al., 1996). Beyond the scope of the Algerian margin, such kind of inversion model may be applied to other inverted margins, for example, the Palomares margin in southern Spain (Giaconia et al., 2015) or the north-Sicilian margin in the south Tyrrhenian sea (Billi et al., 2007). 


\section{Acknowledgments}

This research was funded by the French National Research Agency (ANR, Agence Nationale de la Recherche) under the Project ANR-06-CATT-005 DANACOR Déformations Actives au Nord de l'Afrique, des Chaînes à l'Océan: Vers une évaluation des Risques géologiques associés. Christian Romano is greatly acknowledged for his efficient technical support in performing the analog experiments. We are grateful to the Editor Laurent Jolivet and to three reviewers for their constructive comments.

\section{References}

Abbassene, F., Chazot, G., Bellon, H., Bruguier, O., Ouabadi, A., Maury, R. C., et al. (2016). A 17 Ma onset for the post-collisional K-rich calc-alkaline magmatism in the Maghrebides: Evidence from Bougaroun (northeastern Algeria) and geodynamic implications. Tectonophysics, 674, 114-134. https://doi.org/10.1016/j.tecto.2016.02.013

Aïdi, C., Beslier, M. O., Yelles-Chaouche, A. K., Klingelhoefer, F., Bracene, R., Galve, A., et al. (2018). Deep structure of the continental margin and basin off Greater Kabylia, Algeria - new insights from wide-angle seismic data modeling and multichannel seismic interpretation. Tectonophysics, 728-729, 1-22. https://doi.org/10.1016/j.tecto.2018.01.007

Aïte, M. O., \& Gélard, J. P. (1997). Distension néogène post-collisionnelle sur le transect de Grande-Kabylie (Algérie). Bulletin de La Societe Geologique de France. 168, 423-436.

Authemayou, C., Pedoja, K., Heddar, A., Molliex, S., Boudiaf, A., Ghaleb, B., et al. (2017). Coastal uplift west of Algiers (Algeria): Pre- and post-Messinian sequences of marine terraces and rasas and their associated drainage pattern. International Journal of Earth Sciences, 106, 19-41. https://doi.org/10.1007/s00531-016-1292-5

Ayadi, A., Maouche, S., Harbi, A., Meghraoui, M., Beldjoudi, H., Oussadou, F., et al. (2003). Strong Algerian earthquake strikes near Capital city. Eos, 84(50). https://doi.org/10.1029/2003eo500002

Babonneau, N., Cattaneo, A., Ratzov, G., Déverchère, J., Yelles-Chaouche, A., Lateb, T., \& Bachir, R. S. (2017). Turbidite chronostratigraphy off Algiers, central Algerian margin: A key for reconstructing Holocene paleo-earthquake cycles. Marine Geology, 384, 63-80. https:// doi.org/10.1016/j.margeo.2016.10.017

Beltrando, M., Manatschal, G., Mohn, G., Dal Piaz, G. V., Vitale Brovarone, A., \& Masini, E. (2014). Recognizing remnants of magma-poor rifted margins in high-pressure orogenic belts: The Alpine case study. Earth-Science Reviews, 88-115. https://doi.org/10.1016/j. earscirev.2014.01.001

Benaouali-Mebarek, N., Frizon de Lamotte, D., Roca, E., Bracene, R., Faure, J. L., Sassi, W., \& Roure, F. (2006). Post-Cretaceous kinematics of the Atlas and Tell systems in central Algeria: Early foreland folding and subduction-related deformation. Comptes Rendus - Geoscience, 338, 115-125. https://doi.org/10.1016/j.crte.2005.11.005

Billi, A., Presti, D., Faccenna, C., Neri, G., \& Orecchio, B. (2007). Seismotectonics of the Nubia plate compressive margin in the south Tyrrhenian region, Italy: Clues for subduction inception. Journal of Geophysical Research: Solid Earth, 112(8), https://doi. org/10.1029/2006JB004837

Boudiaf, A. (1996). Etude sismotectonique de la région d'Alger et de la Kabylie (Algérie): Utilisation des modèles numériques de terrain (MNT) et de la télédétection pour la reconnaissance des structures tectoniques actives: Contribution à l'évaluation de l'aléa sismique. Ph.D. thesis. p. 274. Univ. de Montpellier II, Montpellier, France.

Boudiaf, A., Philip, H., Coutelle, A., \& Ritz, J. F. (1999). Evidence of a major quaternary thrust fault in southern Kabylie (Algeria). Geodinamica Acta, 12, 71-80. https://doi.org/10.1016/S0985-3111(99)80024-2

Boudiaf, A., Ritz, J. F., \& Philip, H. (1998). Drainage diversions as evidence of propagating active faults: Example of the El Asnam and Thenia faults, Algeria. Terra Nova. https://doi.org/10.1046/j.1365-3121.1998.00197.x

Bougrine, A., Yelles-Chaouche, A. K., \& Calais, E. (2019). Active deformation in Algeria from continuous GPS measurements. Geophysical Journal International, 217, 572-588. https://doi.org/10.1093/gji/ggz035

Bouillin, J. P. (1986). Le "bassin maghrebin"; une ancienne limite entre l'Europe et l'Afrique a l'ouest des Alpes. Bulletin de La Société Géologique de France, 2, 547-558. https://doi.org/10.2113/gssgfbull.ii.4.547

Bounif, A., Dorbath, C., Ayadi, A., Meghraoui, M., Beldjoudi, H., Laouami, N., et al. (2004). The 21 May 2003 Zemmouri (Algeria) earthquake $M_{w}$ 6.8: Relocation and aftershock sequence analysis. Geophysical Research Letters, 31(19), https://doi.org/10.1029/ 2004GL020586

Bouyahiaoui, B., Sage, F., Abtout, A., Klingelhoefer, F., Yelles-Chaouche, K., Schnürle, P., et al. (2015). Crustal structure of the eastern Algerian continental margin and adjacent deep basin: Implications for late Cenozoic geodynamic evolution of the western Mediterranean. Geophysical Journal International, 201, 1912-1938. https://doi.org/10.1093/gii/ggv102

Bracène, R., \& Frizon de Lamotte, D. (2002). The origin of intraplate deformation in the Atlas system of western and central Algeria: From Jurassic rifting to Cenozoic-Quaternary inversion. Tectonophysics, 357, 207-226. https://doi.org/10.1016/ S0040-1951(02)00369-4

Burbank, D., Meigs, A., \& Brozović, N. (1996). Interactions of growing folds and coeval depositional systems. Basin Research, 8, 199-223. https://doi.org/10.1046/j.1365-2117.1996.00181.x

Byerlee, J. (1978). Friction of rocks. Pure and Applied Geophysics, 116, 615-626. https://doi.org/10.1007/BF00876528

Caby, R., Hammor, D., \& Delor, C. (2001). Metamorphic evolution, partial melting and Miocene exhumation of lower crust in the Edough metamorphic core complex, West Mediterranean orogen, eastern Algeria. Tectonophysics, 342, 239-273. https://doi.org/10.1016/ S0040-1951(01)00166-4

Carmignani, L., Funedda, A., Oggiano, G., \& Pasci, S. (2004). Tectono-sedimentary evolution of southwest Sardinia in the Paleogene: Pyrenaic or apenninic dynamic? Geodinamica Acta, 17, 275-287. https://doi.org/10.3166/ga.17.275-287

Carminati, E., Wortel, M. J. R., Meijer, P. T., \& Sabadini, R. (1998). The two-stage opening of the western-central Mediterranean basins: A forward modeling test to a new evolutionary model. Earth and Planetary Science Letters, 160, 667-679. https://doi.org/10.1016/ S0012-821X(98)00119-8

Cerca, M., Ferrari, L., Corti, G., Bonini, M., \& Manetti, P. (2010). Analog model of inversion tectonics explaining the structural diversity of Late Cretaceous shortening in southwestern Mexico. Lithosphere, 2, 172-187. https://doi.org/10.1130/L48.1

Chazot, G., Abbassene, F., Maury, R. C., Déverchère, J., Bellon, H., Ouabadi, A., \& Bosch, D. (2017). An overview on the origin of post-collisional Miocene magmatism in the Kabylies (northern Algeria): Evidence for crustal stacking, delamination and slab detachment. Journal of African Earth Sciences, 125, 27-41. https://doi.org/10.1016/j.jafrearsci.2016.10.005

CIESM. (2008). The Messinian salinity crisis from mega-depositstion microbiology. In F. Briand (Ed.), A consensus report, in 33ème CIESM Workshop Monographs. 33 (pp. 1-168). Monaco: CIESM. 
Clauzon, G., Suc, J. P., Couto, D. D., Jouannic, G., Melinte-Dobrinescu, M. C., Jolivet, L., et al. (2015). New insights on the Sorbas Basin (SE Spain): The onshore reference of the Messinian Salinity Crisis. Marine and Petroleum Geology, 66, 71-100. https://doi.org/10.1016/j. marpetgeo.2015.02.016

Clauzon, G., Suc, J. P., Gautier, F., Berger, A., \& Loutre, M. F. (1996). Alternate interpretation of the Messinian salinity crisis: Controversy resolved? Geology. https://doi.org/10.1130/0091-7613(1996)024<0363:AIOTMS > 2.3.CO;2

Cobbold, P. R., \& Jackson, M. P. A. (1992). Gum rosin (colophony): A suitable material for thermomechanical modelling of the lithosphere. Tectonophysics, 210, 255-217. https://doi.org/10.1016/0040-1951(92)90325-Z

Coward, M. P. (1996). Balancing sections through inverted basins. Geological Society Special Publication, 99, 51-77. https://doi.org/10.1144/ GSL.SP.1996.099.01.06

Coward, M. P., Gillcrist, R., \& Trudgill, B. (1991). Extensional structures and their tectonic inversion in the Western Alps. Geological Society Special Publication, 56, 93-112. https://doi.org/10.1144/GSL.SP.1991.056.01.07

Dal Cin, M., Del Ben, A., Mocnik, A., Accaino, F., Geletti, R., Wardell, N., et al. (2016). Seismic imaging of late Miocene (Messinian) evaporites from Western Mediterranean back-arc basins. Petroleum Geoscience, 22, 297-308. https://doi.org/10.1144/petgeo2015-096

Dan-Unterseh, G., Savoye, B., Gaullier, V., Cattaneo, A., Déverchère, J., \& Yelles-Chaouche, A. K. (2011). Algerian Margin Sedimentation Patterns (Algiers Area, Southwestern Mediterranean). Mass-transport deposits in deepwater settings. 69-84. https://doi.org/10.2110/ sepmsp.096.069

Dan, G., Sultan, N., Cattaneo, A., Déverchère, J., \& Yelles, K. (2010). Mass-transport deposits on the Algerian margin (Algiers Area): Morphology, lithology and sedimentary processes. Submarine mass movements and their consequences-4th International Symposium. 527-539. https://doi.org/10.1007/978-90-481-3071-9_43

Dan, G., Sultan, N., Savoye, B., Déverchère, J., \& Yelles, K. (2009). Quantifying the role of sandy-silty sediments in generating slope failures during earthquakes: Example from the Algerian margin. International Journal of Earth Sciences, 98, 769-789. https://doi.org/10.1007/ s00531-008-0373-5

Davy, P., \& Cobbold, P. R. (1991). Experiments on shortening of a 4-layer model of the continental lithosphere. Tectonophysics, 188, 1-25. https://doi.org/10.1016/0040-1951(91)90311-F

Delouis, B., Vallée, M., Meghraoui, M., Calais, E., Maouche, S., Lammali, K., et al. (2004). Slip distribution of the 2003 Boumerdes-Zemmouri earthquake, Algeria, from teleseismic, GPS, and coastal uplift data. Geophysical Research Letters, 31(18), https://doi. org/10.1029/2004GL020687

De Lamotte, D. F., Bezar, B., Saint, B. R., \& Mercier, E. (2000). The two main steps of the atlas building and geodynamics of the Western Mediterranean. Tectonics, 19, 740-761. https://doi.org/10.1029/2000TC900003

de Lamotte, D. F., Leturmy, P., Missenard, Y., Khomsi, S., Ruiz, G., Saddiqi, O., et al. (2009). Mesozoic and Cenozoic vertical movements in the Atlas system (Algeria, Morocco, Tunisia): An overview. Tectonophysics, 475, 9-28. https://doi.org/10.1016/j.tecto.2008.10.024

DeMets, C., Iaffaldano, G., \& Merkouriev, S. (2015). High-resolution Neogene and Quaternary estimates of Nubia-Eurasia-north America Plate motion. Geophysical Journal International, 203, 416-427. https://doi.org/10.1093/gji/ggv277

Déverchère, J., Mercier De Lépinay, B., Cattaneo, A., Strzerzynski, P., Calais, E., Domzig, A., \& Bracene, R. (2010). Comment on "Zemmouri earthquake rupture zone $\left(M_{w} 6.8\right.$, Algeria): Aftershocks sequence relocation and 3D velocity model” by A. Ayadi et al. Journal of Geophysical Research, 115(4), https://doi.org/10.1029/2008JB006190

Déverchère, J., Yelles, K., Domzig, A., Mercier de Lépinay, B., Bouillin, J. P., Gaullier, V., et al. (2005). Active thrust faulting offshore offshore Boumerdes, Algeria, and its relations to the $2003 M_{w} 6.9$ earthquake. Geophysical Research Letters, 32, 1-5. https://doi. org/10.1029/2004GL021646

Dewey, J. F., Helman, M. L., Knott, S. D., Turco, E., \& Hutton, D. H. W. (1989). Kinematics of the western Mediterranean. Geological Society Special Publication, 45, 265-283. https://doi.org/10.1144/GSL.SP.1989.045.01.15

Domzig, A., Yelles, K., Le Roy, C., Déverchère, J., Bouillin, J. P., Bracène, R., et al. (2006). Searching for the Africa-Eurasia Miocene boundary offshore western Algeria (MARADJA'03 cruise). Comptes Rendus - Geoscience, 338, 80-91. https://doi.org/10.1016/j.crte.2005.11.009

Duvail, C., Gorini, C., Lofi, J., Le Strat, P., Clauzon, G., \& dos Reis, A. T. (2005). Correlation between onshore and offshore Pliocene-Quaternary systems tracts below the Roussillon Basin (eastern Pyrenees, France). Marine and Petroleum Geology, 22, 747-756. https://doi. org/10.1016/j.marpetgeo.2005.03.009

Erdos, Z., Huismans, R. S., Van Der Beek, P., \& Thieulot, C. (2014). Extensional inheritance and surface processes as controlling factors of mountain belt structure. Journal of Geophysical Research: Solid Earth, 119, 9042-9061. https://doi.org/10.1002/2014JB011408

Garcia-Castellanos, D., Estrada, F., Jiménez-Munt, I., Gorini, C., Fernández, M., Vergés, J., \& De Vicente, R. (2009). Catastrophic flood of the Mediterranean after the Messinian salinity crisis. Nature, 462, 778-781. https://doi.org/10.1038/nature08555

Gautier, F., Clauzon, G., Suc, J. P., Cravatte, J., \& Violanti, D. (1994). Age et duree de la crise de salinite messinienne. Comptes Rendus Acad. des Sci. Ser. II Sci. la Terre des Planetes.

Graveleau, F., Hurtrez, J. E., Dominguez, S., \& Malavieille, J. (2011). A new experimental material for modeling relief dynamics and interactions between tectonics and surface processes. Tectonophysics, 513, 68-87. https://doi.org/10.1016/j.tecto.2011.09.029

Graveleau, F., Malavieille, J., \& Dominguez, S. (2012). Experimental modelling of orogenic wedges: A review. Tectonophysics, https://doi. org/10.1016/j.tecto.2012.01.027

Graveleau, F., Strak, V., Dominguez, S., Malavieille, J., Chatton, M., Manighetti, I., \& Petit, C. (2015). Experimental modelling of tectonics-erosion-sedimentation interactions in compressional, extensional, and strike-slip settings. Geomorphology, 244, 146-168. https://doi. org/10.1016/j.geomorph.2015.02.011

Giaconia, F., Booth-Rea, G., Ranero, C. R., Gràcia, E., Bartolome, R., Calahorrano, A., et al. (2015). Compressional tectonic inversion of the Algero-Balearic basin: Latemost Miocene to present oblique convergence at the Palomares margin (Western Mediterranean). Tectonics, 34, 1516-1543. https://doi.org/10.1002/2015TC003861

Govers, R., Meijer, P., \& Krijgsman, W. (2009). Regional isostatic response to Messinian Salinity Crisis events. Tectonophysics, 463, 109-129. https://doi.org/10.1016/j.tecto.2008.09.026

Graveleau, F., \& Dominguez, S. (2008). Analog modeling of the interaction between tectonics, erosion and sedimentation in foreland thrust belts. Comptes Rendus - Geoscience, 340, 324-333. https://doi.org/10.1016/j.crte.2008.01.005

Gueguen, E., Doglioni, C., \& Fernandez, M. (1998). On the post-25 Ma geodynamic evolution of the western Mediterranean. Tectonophysics, 298, 259-269. https://doi.org/10.1016/S0040-1951(98)00189-9

Guerit, L., Dominguez, S., Malavieille, J., \& Castelltort, S. (2016). Deformation of an experimental drainage network in oblique collision. Tectonophysics, 693, 210-222. https://doi.org/10.1016/j.tecto.2016.04.016

Hamai, L., Petit, C., Abtout, A., Yelles-Chaouche, A., \& Déverchère, J. (2015). Flexural behaviour of the north Algerian margin and tectonic implications. Geophysical Journal International, 201, 1426-1436. https://doi.org/10.1093/gji/ggv098 
Hamai, L., Petit, C., Le Pourhiet, L., Yelles-Chaouche, A., Déverchère, J., Beslier, M. O., \& Abtout, A. (2018). Towards subduction inception along the inverted north African margin of Algeria? Insights from thermo-mechanical models. Earth and Planetary Science Letters, 501, 13-23. https://doi.org/10.1016/j.epsl.2018.08.028

Heddar, A., Authemayou, C., Djellit, H., Yelles, A. K., Déverchère, J., Gharbi, S., et al. (2013). Preliminary results of a paleoseismological analysis along the Sahel fault (Algeria): New evidence for historical seismic events. Quaternary International, 302, 210-223. https://doi. org/10.1016/j.quaint.2012.09.007

Hodell, D. A., Curtis, C. H., Sierro, F. J., \& Raymo, M. E. (2001). Correlation of late Miocene to early Pliocene sequences between the Mediterranean and north Atlantic. Paleoceanography, 16(2), 164-178.

Hsü, K. J., Montadert, L., Bernoulli, D., Cita, M. B., Erickson, A., Garrison, R. E., etal. (1977). History of the mediterranean salinity crisis. Nature. https://doi.org/10.1038/267399a0

Hoek, E., \& Brown, E. T. (2019). The Hoek-Brown failure criterion and GSI - 2018 edition. Journal of Rock Mechanics and Geotechnical Engineering, 11, 445-463. https://doi.org/10.1016/j.jrmge.2018.08.001

Jolivet, L., \& Faccenna, C. (2000). Meditterranean extension and the Africa-Eurasia collision. Tectonics, 19, 1095-1106. https://doi. org/10.1029/2000TC900018

Kherroubi, A., Déverchère, J., Yelles, A., Mercier de Lépinay, B., Domzig, A., Cattaneo, A., et al. (2009). Recent and active deformation pattern off the easternmost Algerian margin, Western Mediterranean Sea: New evidence for contractional tectonic reactivation. Marine Geology, 261, 17-32. https://doi.org/10.1016/j.margeo.2008.05.016

Kherroubi, A., Yelles-Chaouche, A., Koulakov, I., Déverchère, J., Beldjoudi, H., Haned, A., et al. (2017). Full Aftershock Sequence of the M w 6.92003 Boumerdes Earthquake, Algeria: Space-time distribution, local tomography and Seismotectonic implications. Pure and Applied Geophysics, 174, 2495-2521. https://doi.org/10.1007/s00024-017-1571-5

Kim, G. B., Yoon, S. H., Kim, S. S, \& So, B. D. (2018). Transition from buckling to subduction on strike-slip continental margins: Evidence from the East Sea (Japan Sea). Geology, https://doi.org/10.1130/G40305.1

King Hubbert, M., (1951). Mechanical basis for certain familiar geologic structures. Bull. Geol. Soc. Am, 62, 355-372. https://doi.org/10.1 130/0016-7606(1951)62[355:MBFCFG]2.0.CO;2

King Hubbert, M., (1937). Theory of scale models as applied to the study of geologic structures. Bull. Geol. Soc. Am. 48, 1459-1520. https:// doi.org/10.1130/GSAB-48-1459

Leprêtre, R., Frizon de Lamotte, D. F., Combier, V., Gimeno-Vives, O., Mohn, G., \& Eschard, R. (2018). The Tell-Rif orogenic system (Morocco, Algeria, Tunisia) and the structural heritage of the southern Tethys margin. BSGF - Earth Sciences Bulletin, 189(2), -. https://doi org/10.1051/bsgf/2018009

Leprêtre, A., Klingelhoefer, F., Graindorge, D., Schnurle, P., Beslier, M. O., Yelles, K., et al. (2013). Multiphased tectonic evolution of the Central Algerian margin from combined wide-angle and reflection seismic data off Tipaza, Algeria. Journal of Geophysical Research: Solid Earth, 118, 3899-3916. https://doi.org/10.1002/jgrb.50318

Lofi, J., Déverchère, J., Gaullier, V., Gillet, H., Gorini, C., Guennoc, P., et al. (2011). Seismic Atlas of the Messinian Salinity Crisis markers in the Mediterranean and Black Seas. Mémoires de la Société Géologique de France and Commission for the Geological Map of the World, 179, 72. 1CD, ISBN 2-85363-097-8.

Lofi, J., Gorini, C., Berné, S., Clauzon, G., Dos Reis, A. T., Ryan, W. B. F., \& Steckler, M. S. (2005). Erosional processes and paleo-environmental changes in the Western Gulf of Lions (SW France) during the Messinian Salinity Crisis. Marine Geology, 217, 1-30. https://doi. org/10.1016/j.margeo.2005.02.014

Lofi, J., Sage, F., Deverchere, J., Loncke, L., Maillard, A., Gaullier, V., et al. (2011). Refining our knowledge of the Messinian salinity crisis records in the offshore domain through multi-site seismic analysis. Bulletin de La Societe Geologique de France, 182, 163-180. https:// doi.org/10.2113/gssgfbull.182.2.163

Mahsas, A., Lammali, K., Yelles, K., Calais, E., Freed, A. M., \& Briole, P. (2008). Shallow afterslip following the 2003 May $21, M_{w}=6.9$ Boumerdes earthquake, Algeria. Geophysical Journal International, 172, 155-166. https://doi.org/10.1111/j.1365-246X.2007.03594.x

Malavieille, J. (2010). Impact of erosion, sedimentation, and structural heritage on the structure and kinematics of orogenic wedges: Analog models and case studies. GSA Today, 20, 4-10. https://doi.org/10.1130/GSATG48A.1

Mauffret, A. (2007). The Northwestern (Maghreb) boundary of the Nubia (Africa) Plate. Tectonophysics, 429, 21-44. https://doi. org/10.1016/j.tecto.2006.09.007

Maury, R., Fourcade, S., Coulon, C., El Azzouzi, M., Bellon, H., Coutelle, A., et al. (2000). Post-collisional Neogene magmatism of the Mediterranean Maghreb margin: A consequence of slab breakoff. Comptes Rendus de l'Academie de Sciences - Serie IIa: Sciences de La Terre et Des Planetes, 331, 159-173. https://doi.org/10.1016/S1251-8050(00)01406-3

McClay, K. R. (1989). Analog models of inversion tectonics. Geological Society Special Publication, 44, 41-59. https://doi.org/10.1144/GSL. SP.1989.044.01.04

Meghraoui, M. (1991). Blind reverse faulting system associated with the Mont Chenoua-Tipaza earthquake of 29 October 1989 (north-central Algeria). Terra Nova, 3, 84-92. https://doi.org/10.1111/j.1365-3121.1991.tb00847.x

Norman, S. E., \& Chase, C. G. (1986). Uplift of the shores of the western mediterranean due to messinian desiccation and flexural isostasy. Nature. https://doi.org/10.1038/322450a0

Ousadou, F., \& Bezzeghoud, M. (2019). Seismicity of the Algerian tell atlas and the impacts of major earthquakes. In Springer Geology 401-426. https://doi.org/10.1007/978-3-319-96794-3_11

Paola, C., Straub, K., Mohrig, D., \& Reinhardt, L. (2009). The “unreasonable effectiveness” of stratigraphic and geomorphic experiments. Earth-Science Reviews, 97, 1-43. https://doi.org/10.1016/j.earscirev.2009.05.003

Pfiffner, O. A. (2017). Thick-skinned and thin-skinned tectonics: A global perspective. Geosciences (Switzerland), 7(3), https://doi. org/10.3390/geosciences7030071

Rabaute, A., \& Chamot-Rooke, N. (2014). Active Tectonics of Africa-Eurasia boundary from Algiers to Calabria. Map 1:1 500000ème, Paris, ISBN 978-2-9548197-0-9.

Rabineau, M., Leroux, E., Aslanian, D., Bache, F., Gorini, C., Moulin, M., et al. (2014). Quantifying subsidence and isostatic readjustment using sedimentary paleomarkers, example from the Gulf of Lion. Earth and Planetary Science Letters. https://doi.org/10.1016/j. epsl.2013.11.059

Raymond, D. (1976). Evolution sédimentaire et tectonique du Nord-Ouest de la Grande Kabylie (Algérie) au cours du cycle alpin. Thèse d'état Université Pierre et Marie Curie, p. 160.

Recanati, A., Missenard, Y., Leprêtre, R., Gautheron, C., Barbarand, J., Abbassene, F., et al. (2019). A Tortonian onset for the Algerian margin inversion: Evidence from low-temperature thermochronology. Terra Nova, 31, 39-48. https://doi.org/10.1111/ter.12367 
Richard, P. (1991). Experiments on faulting in a two-layer cover sequence overlying a reactivated basement fault with oblique-slip. Journal of Structural Geology, 13, 459-469. https://doi.org/10.1016/0191-8141(91)90018-E

Roca, E., Frizon de Lamotte, D., Mauffret, A., Bracène, R., Vergés, J., Benaouali, N., et al. (2004). TRANSMED Transect II. In W. Cavazza, F. Roure, W. Spakman, G. M. Stampfli, \& P. A. Ziegler (Eds.), The TRANSMED Atlas - the Mediterranean region from crust to mantle. Berlin Heidelberg: Springer.

Rosenbaum, G., \& Lister, G. S. (2004). Formation of arcuate orogenic belts in the western Mediterranean region. Special Paper of the Geological Society of America, 383, 41-56. https://doi.org/10.1130/0-8137-2383-3(2004)383[41:FOAOBI]2.0.CO;2

Roure, F., Casero, P., \& Addoum, B. (2012). Alpine inversion of the North African margin and delamination of its continental lithosphere. Tectonics, 31(3), https://doi.org/10.1029/2011TC002989

Roveri, M., Gennari, R., Ligi, M., Lugli, S., Manzi, V., \& Reghizzi, M. (2019). The synthetic seismic expression of the Messinian salinity crisis from onshore records: Implications for shallow- to deep-water correlations. Basin Research, 31, 1121-1152. https://doi.org/10.1111/ bre. 12361

Rubino, J. L., \& Clauzon, G. (2008). Upper Miocene and Pliocene Key surfaces, stratigraphic markers used to quantify Peri-Mediterranean geodynamics (Abstract). In: Géodynamique et paléogéographie de l'aire méditerranéenne au Mio-Pliocène: l'inteférence eustasie/tectonique. Séance spécialisée Soc. Géol. France, Villeurbanne, France, 63-65, 5-6 May.

Rubino, J. L., Haddadi, N., Clauzon, G., \& Mesla, H. (2005). Algiers Pliocene Ria: A Messinian Canyon filled by Gilbert delta complexes. EAGE Meeting, Algiers Abstract.

Ryan, W. B. F. (2011). Geodynamic responses to a two-step model of the Messinian salinity crisis. Bulletin de La Societe Geologique de France, 182, 73-78. https://doi.org/10.2113/gssgfbull.182.2.73

Ryan, W. B. F., \& Cita, M. B. (1978). The nature and distribution of Messinian erosional surfaces - Indicators of a several-kilometer-deep Mediterranean in the Miocene. Marine Geology, 27, 193-230. https://doi.org/10.1016/0025-3227(78)90032-4

Sage, F., Von Gronefeld, G., Déverchère, J., Gaullier, V., Maillard, A., \& Gorini, C. (2005). Seismic evidence for Messinian detrital deposits at the western Sardinia margin, northwestern Mediterranean. Marine and Petroleum Geology, 22, 757-773. https://doi.org/10.1016/j. marpetgeo.2005.03.007

Schellart, W. P., \& Strak, V. (2016). A review of analog modelling of geodynamic processes: Approaches, scaling, materials and quantification, with an application to subduction experiments. Journal of Geodynamics, 100, 7-32. https://doi.org/10.1016/j.jog.2016.03.009

Schettino, A., \& Turco, E. (2006). Plate kinematics of the Western Mediterranean region during the Oligocene and Early Miocene. Geophysical Journal International, 166, 1398-1423. https://doi.org/10.1111/j.1365-246X.2006.02997.x

Serpelloni, E., Vannucci, G., Pondrelli, S., Argnani, A., Casula, G., Anzidei, M., et al. (2007). Kinematics of the Western Africa-Eurasia plate boundary from focal mechanisms and GPS data. Geophysical Journal International, 169, 1180-1200. https://doi. org/10.1111/j.1365-246X.2007.03367.x

Shail, R. K., \& Leveridge, B. E. (2009). The Rhenohercynian passive margin of SW England: Development, inversion and extensional reactivation. Comptes Rendus - Geoscience, 341, 140-155. https://doi.org/10.1016/j.crte.2008.11.002

Shemenda, A. I. (1983). Similarity criteria in mechanical modeling of tectonic processes Soviet. Geology and Geophysics, 24, 8-16.

Stern, R. J., \& Gerya, T. (2018). Subduction initiation in nature and models: A review. Tectonophysics, 746, 173-198. https://doi.org/10.1016/j. tecto.2017.10.014

Stock, G. M., Frankel, K. L., Ehlers, T. A., Schaller, M., Briggs, S. M., \& Finkel, R. C. (2009). DKJ StartSpatial and temporal variations in denudation of the Wasatch Mountains, Utah, USA. Lithosphere, 1, 34-40. https://doi.org/10.1130/L15.1

Strak, V., Dominguez, S., Petit, C., Meyer, B., \& Loget, N. (2011). Interaction between normal fault slip and erosion on relief evolution: Insights from experimental modelling. Tectonophysics, 513, 1-19. https://doi.org/10.1016/j.tecto.2011.10.005

Strzerzynski, P., Déverchère, J., Cattaneo, A., Domzig, A., Yelles, K., Mercier de Lépinay, B., et al. (2010). Tectonic inheritance and Pliocene-Pleistocene inversion of the Algerian margin around Algiers: Insights from multibeam and seismic reflection data. Tectonics, 29(2), https://doi.org/10.1029/2009tc002547

Tucker, G. E., McCoy, S. W., Whittaker, A. C., Roberts, G. P., Lancaster, S. T., \& Phillips, R. (2011). Geomorphic significance of postglacial bedrock scarps on normal-fault footwalls. Journal of Geophysical Research Earth Surface. https://doi.org/10.1029/2010JF001861

Turner, J. P., \& Williams, G. A. (2004). Sedimentary basin inversion and intra-plate shortening. Earth-Science Reviews, 65, 277-304. https:// doi.org/10.1016/j.earscirev.2003.10.002

van Hinsbergen, D. J. J., Torsvik, T. H., Schmid, S. M., Maţenco, L. C., Maffione, M., Vissers, R. L. M., et al. (2020). Orogenic architecture of the Mediterranean region and kinematic reconstruction of its tectonic evolution since the Triassic. Gondwana Research, 81, 79-229. https://doi.org/10.1016/j.gr.2019.07.009

van Hinsbergen, D. J. J., Vissers, R. L. M., \& Spakman, W. (2014). Origin and consequences of western Mediterranean subduction, rollback, and slab segmentation. Tectonics, 33, 393-419. https://doi.org/10.1002/2013TC003349

Vail, P. R., \& Mitchum, R. M. (1977). Seismic Stratigraphy and Global Changes of Sea Level, Part 1: AAPG Mem. 26.

Vanbrabant, Y., Braun, J., \& Jongmans, D. (2002). Models of passive margin inversion: Implications for the Rhenohercynian fold-andthrust belt, Belgium and Germany. Earth and Planetary Science Letters, 202, 15-29. https://doi.org/10.1016/S0012-821X(02)00751-3

Villaplana-Muzas, M., Babault, J., Dominguez, S., Van Den Driessche, J., \& Legrand, X. (2015). Drainage network evolution and patterns of sedimentation in an experimental wedge. Tectonophysics. https://doi.org/10.1016/j.tecto.2015.09.007

Wildi, W. (1983). La chaîne tello-rifaine (Algérie, Maroc, Tunisie): Structure, stratigraphie et évolution du Trias au Miocène. Revue de Geographie Physique et de Geologie Dynamique, 24, 201-297.

Williams, G. D., Powell, C. M., \& Cooper, M. A. (1989). Geometry and kinematics of inversion tectonics. Geological Society Special Publication, 44, 3-15. https://doi.org/10.1144/GSL.SP.1989.044.01.02

Yelles-Chaouche, A. K., Boudiaf, A., Djellit, H., \& Bracene, R. (2006). La tectonique active de la région nord-algérienne. Comptes Rendus Geoscience, 338, 126-139. https://doi.org/10.1016/j.crte.2005.11.002

Yelles, A., Domzig, A., Déverchère, J., Bracène, R., Mercier de Lépinay, B., Strzerzynski, P., et al. (2009). Plio-Quaternary reactivation of the Neogene margin off NW Algiers, Algeria: The Khayr al Din bank. Tectonophysics, 475(1), 98-116. https://doi.org/10.1016/j. tecto.2008.11.030

Ziegler, P. A., Cloetingh, S., \& van Wees, J. D. (1995). Dynamics of intra-plate compressional deformation: The Alpine foreland and other examples. Tectonophysics, 252, 7-59. https://doi.org/10.1016/0040-1951(95)00102-6 